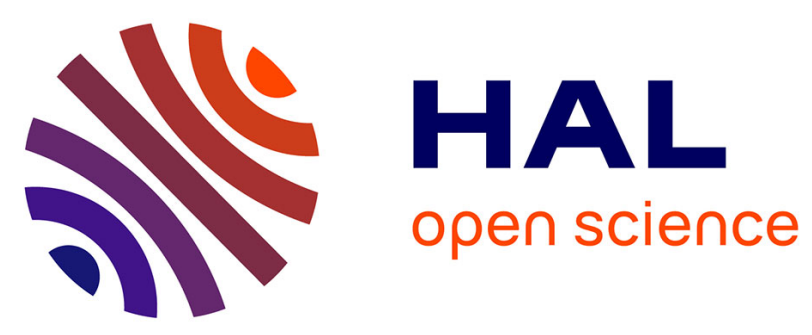

\title{
Foraging habits and levels of mercury in a resident population of bottlenose dolphins (Tursiops truncatus) in Bocas del Toro Archipelago, Caribbean Sea, Panama
}

Dalia Barragán-Barrera, Andrea Luna-Acosta, Laura May-Collado, Carlos Polo-Silva, Federico Riet-Sapriza, Paco Bustamante, María Paula

Hernández-Ávila, Natalia Vélez, Nohelia Farías-Curtidor, Susana Caballero

\section{To cite this version:}

Dalia Barragán-Barrera, Andrea Luna-Acosta, Laura May-Collado, Carlos Polo-Silva, Federico RietSapriza, et al.. Foraging habits and levels of mercury in a resident population of bottlenose dolphins (Tursiops truncatus) in Bocas del Toro Archipelago, Caribbean Sea, Panama. Marine Pollution Bulletin, 2019, 145, pp.343-356. 10.1016/j.marpolbul.2019.04.076 . hal-02334307

\section{HAL Id: hal-02334307 https://hal.science/hal-02334307}

Submitted on 25 Oct 2019

HAL is a multi-disciplinary open access archive for the deposit and dissemination of scientific research documents, whether they are published or not. The documents may come from teaching and research institutions in France or abroad, or from public or private research centers.
L'archive ouverte pluridisciplinaire HAL, est destinée au dépôt et à la diffusion de documents scientifiques de niveau recherche, publiés ou non, émanant des établissements d'enseignement et de recherche français ou étrangers, des laboratoires publics ou privés. 


\title{
Foraging habits and levels of mercury in a resident population of bottlenose dolphins
}

(Tursiops truncatus) in Bocas del Toro Archipelago, Caribbean Sea, Panama

\begin{abstract}
Authors
Dalia C. Barragán-Barrera ${ }^{1,2,3^{*}}$, Andrea Luna-Acosta ${ }^{4}$, Laura J. May-Collado ${ }^{5,6}$, Carlos Polo-Silva $^{7}$, Federico G. Riet-Sapriza ${ }^{1}$, Paco Bustamante ${ }^{8}$, María Paula Hernández-Ávila ${ }^{1}$, Natalia Vélez ${ }^{4}$, Nohelia Farías-Curtidor ${ }^{2}$ and Susana Caballero ${ }^{1}$

${ }^{1}$ Laboratorio de Ecología Molecular de Vertebrados Acuáticos-LEMVA, Departamento de Ciencias Biológicas, Universidad de los Andes, Carrera 1 \# 18A-10, Bogotá, Colombia.

${ }^{2}$ Fundación Macuáticos Colombia, Calle 27 \# 79-167, Medellín, Colombia.

${ }^{3}$ Young Researcher, Corporation Center of Excellence in Marine Sciences-CEMarin, Carrera 21 \# 35-53, Bogotá, Colombia.

${ }^{4}$ Departamento de Ecología y Territorio, Facultad de Estudios Ambientales y Rurales, Pontificia Universidad Javeriana, Transversal 4 \# 42-00, Bogotá, Colombia.

${ }^{5}$ Department of Biology, University of Vermont, 109 Carrigan Drive, Burlington, VT 05405, USA.

${ }^{6}$ Centro de Investigación en Ciencias del Mar y Limnología, Universidad de Costa Rica, Costa Rica.

${ }^{7}$ Facultad de Ciencias Naturales e Ingeniería, Universidad de Bogotá Jorge Tadeo Lozano, Santa Marta, Colombia

${ }^{8}$ Littoral Environnement et Sociétés (LIENSs) UMR 7266 CNRS-Université de La Rochelle, 2 rue Olympe de Gouges, 17000 La Rochelle, France
\end{abstract}

*Corresponding author: dc.barragan140@ uniandes.edu.co 


\begin{abstract}
A small and genetically isolated bottlenose dolphin (Tursiops truncatus) population that resides year-round in the Bocas del Toro Archipelago-Panama (BDT). Photoidentification and genetic data showed that this dolphin population is highly phylopatric and is formed exclusively by individuals of the "inshore form". This study aimed to investigate the trophic ecology and mercury concentrations of bottlenose dolphin in BDT to assess their coastal habits. We collected muscle samples $(n=175)$ of 11 potential fish prey species, and skin samples from free-ranging dolphins in BDT $(n=37)$ and La Guajira-Colombia $(n=7)$ to compare isotopic niche width. Results showed that BDT dolphins have a coastal feeding habit, belong to the "inshore form" $\left(\delta^{13} \mathrm{C}=-13.05 \pm 1.89 \%\right.$ ), and have low mercury concentrations (mean $=1,637 \pm 1,387 \mathrm{ng} \mathrm{g}^{-1} \mathrm{dw}$ ). However, this element is biomagnified in the BDT food chain, showing a marginal dolphins health risk $(R Q=1.00)$. These results call for preventive dolphin conservation measures and continue monitoring the pollutant levels.
\end{abstract}

Keywords: Tursiops truncatus, inshore form, Bocas del Toro, bioaccumulation, stable isotopes. 


\section{Introduction}

Bottlenose dolphins have a global distribution including tropical, subtropical and temperate marine waters and are opportunistic predators that inhabit a wide range of ecosystems from semi-open coastal environments to the open sea (Reeves et al., 2008), in which factors such as habitat topography and prey availability are known to influence their feeding preferences and foraging strategies (e.g., Smolker et al., 1997; Allen et al., 2001; Blanco et al., 2001; Ingram and Rogan, 2002; Duffy-Echevarría et al., 2008; Allen et al., 2011; Jiménez and Alava, 2013; Browning et al., 2014; Rossman et al., 2015). Given that bottlenose dolphins are opportunistic predator and have global distribution they are considered top predators that can shape the structure of aquatic communities, particularly in coastal ecosystems (Bowen, 1997). Bottlenose dolphin populations around the world that inhabit coastal marine habitats consequently overlaps with human activities that results detrimental for dolphins. This is particularly concerning since coastal dolphin populations are generally small (less than 100 individuals) and show high site philopatry (e.g. Fruet et al., 2014; Vermeulen and Bräger, 2015; Barragán-Barrera et al., 2017; Bayas-Rea et al., 2018), which makes them more vulnerable to human activities than pelagic dolphins populations. For instance, unusual mortality events in coastal dolphins have been associated to exposure of high pollutant concentrations in the Gulf of Mexico (Damseaux et al., 2017). Many coastal bottlenose dolphin populations show genetic isolation and are exposed to pollutants among other threats, and given their global conservation status 'least concern', it is difficult to establish conservation strategies that can effectively mitigate human threats (e.g. Sellas et al., 2005; Parsons et al., 2006; Segura et al., 2006; Fruet et al., 2014; Vermeulen and Bräger, 2015; Barragán-Barrera et al., 2017; Bayas-Rea et al., 2018).

Collecting information about the diet and the foraging habits of bottlenose dolphin's populations is critical to establish conservation and management plans (Hernandez-Milian et al. 2015). The diet of dolphins has been studied primarily via stomach contents, fatty-acid and stable isotope analyses (e.g. Ford et al., 1998; Hooker et al., 2001; Das et al., 2003; Riccialdelli et al., 2010; Milmann et al., 2016). Dietary estimation indicates that coastal bottlenose dolphins prey on cephalopods and a variety of demersal and pelagic fish (Mead 
and Potter, 1990; Van Waerebeek et al., 1990; Blanco et al., 2001; Gannon and Waples, 2004; De Pierrepont et al., 2005; Spitz et al., 2006; Milmann et al., 2016; Moura et al., 2016). However, bottlenose dolphin diet varied in relation to locations and habitats (coastal oceanic) (e.g. Mead and Potter, 1990; 1995; Walker et al., 1999; Gannon and Waples, 2004; Santos et al., 2007; Hernandez-Milian et al., 2015; Milmann et al., 2016), seasons (Gannon and Waples, 2004), sex and reproductive status (e.g. lactating female - pregnant female), and age class (juveniles - adults) (e.g. Blanco et al., 2001; Gannon and Waples, 2004; Santos et al., 2007; Fernández et al., 2011; Hernandez-Milian et al., 2015).

The application of stable isotope analysis (SIA) is a powerful tool that can determine habitat use, trophic position and niche width in marine mammals (Newsome et al., 2006; 2010; Graham et al., 2010). This approach allows for comparisons among tissues, individuals and species, so it has been widely used to assess the trophic ecology of marine top predators such as dolphins, killer whales, sperm whales, leopard seals, sharks, tunas, marlins and swordfish (e.g. Mendes et al., 2007; Méndez-Fernandez et al., 2012; Polo-Silva et al., 2012; 2013; Bisi et al., 2013; Loor-Andrade et al., 2015; Chouvelon et al., 2017; Samarra et al., 2017; Botta et al., 2018; Acosta-Pachón and Ortega-García, 2019).

For example, the isotopic values of carbon $\left(\delta^{13} \mathrm{C}\right)$ and nitrogen $\left(\delta^{15} \mathrm{~N}\right)$ provide an overall insight of an organism diet as it reflects the isotopic composition of prey and foraging habitat (DeNiro and Epstein, 1978; 1981; Newsome et al., 2006; 2010). Due to fractionation, consumers will likely be enriched approximately by $0-1 \%$ in ${ }^{13} \mathrm{C}$ and $2-5 \%$ in ${ }^{15} \mathrm{~N}$ relative to its prey (Peterson and Fry, 1987). Consequently, values of $\delta^{13} \mathrm{C}$ provide information regarding primarily production and diet composition, whereas values of $\delta^{15} \mathrm{~N}$ indicate trophic position. In marine top predators' less depleted values of ${ }^{13} \mathrm{C}$ are associated with feeding coastal areas, and more depleted ${ }^{13} \mathrm{C}$ values correspond to offshore areas. Likewise, high values of $\delta^{15} \mathrm{~N}$ indicate that the consumer is positioned at high levels of the local food web (Graham et al., 2010; Newsome et al., 2010).

Top predators such as bottlenose dolphins have shown high mercury ( $\mathrm{Hg}$ ) concentrations as the result of bioaccumulation with individual age and biomagnification processes in the food 
webs (Fossi et al., 2012). Therefore, Hg can be used as ecological tracer to assess the trophic position in the food chain, since $\mathrm{Hg}$ variations have been associated to age, individual size, and trophic level (Boush and Thieleke, 1983; Power et al., 2002; Cai et al., 2007; Newsome et al., 2010; Kehrig et al., 2013; 2017; Marrugo-Negrete et al., 2018). Hg concentration also varies with location, depth, and distance to the shore (Rivers et al., 1972; Colaco et al., 2006, Choy et al., 2009), with higher $\mathrm{Hg}$ values found in coastal ecosystems largely due to the influence of freshwater inputs and coastal development (Strom and Graves, 2001).

The bottlenose dolphin coastal population in the Archipelago of Bocas del Toro (BDT) in Panama is small (around 80 individuals) and shows high levels of genetic isolation (MayCollado et al., 2015; Barragán-Barrera et al., 2017). This dolphin population share a unique mitochondrial haplotype not found in other Caribbean bottlenose dolphin populations suggesting high philopatry and site fidelity (Barragán-Barrera et al., 2017). Given the high philopatry of BDT's dolphins in the Archipelago, they could be used a sentinel species to monitor the spatial and temporal contaminants trends, like $\mathrm{Hg}$ (Wells et al., 2004; Reif et al., 2015). This element has high level of toxicity and may increase the vulnerability of marine organisms to parasites and infectious agents (Wiener et al., 2003). High Hg concentrations detected in tissues of dolphins (e.g. Leonzio et al., 1992; Frodello et al., 2002; Roditi-Elasar et al., 2003; Aubail et al., 2013; Borrel et al., 2014) have been used to monitor long-term pollution in waters around the Mediterranean Sea (Fossi et al., 2012; Borrel et al., 2014; Shoham-Frider et al., 2016). Although $\mathrm{Hg}$ negative effects have not been measured directly on individuals, declines in the Mediterranean Sea bottlenose dolphin population have been attributed to pollution, so this population has considered as 'vulnerable' by the IUCN (Bearzi et al., 2012). Particularly in BDT, studies on coral and sediment quality have found moderate Hg levels (Guzmán and Jiménez, 1992; Guzmán and García, 2002; Berry et al., 2013). Given the potential negative effects of $\mathrm{Hg}$ on the small and highly philopatric bottlenose dolphin population in BDT, the main aim of this research was to study the foraging ecology and to determine the degree of contamination in dolphins. We also aim to test the hypothesis of whether bottlenose dolphin coastal habits are reflected in their isotopic signatures and $\mathrm{THg}$ concentrations. In order to test this hypothesis, we aimed to achieve the following objectives: a) to measure the total $\mathrm{Hg}(\mathrm{THg})$ concentration, b) stable isotope carbon $\left(\delta^{13} \mathrm{C}\right.$ values $)$ and 
nitrogen ( $\delta^{15} \mathrm{~N}$ values) in muscle of prey fish species from BDT and the skin of bottlenose dolphins in BDT and Guajira (Colombia), and c) to compare the isotopic niche width between these dolphin populations. Assessing coastal habits and monitoring of $\mathrm{Hg}$ in these coastal and vulnerable bottlenose dolphins as top predators in BDT represents important precautionary measures to determine their potential risk health and to facilitate future monitoring.

\section{Materials and Methods}

\subsection{Study area}

The Bocas del Toro Archipelago (BDT) is located on the Northwest Caribbean coast of Panama (Fig. 1). The Archipelago is home to several marine ecosystems including, seagrass, sandy bottom, coral reef, and mangrove forest (Guzmán and García, 2002; D’Croz et al., 2005). Sections of the Archipelago seem to be influenced by open ocean conditions due to water interchange through channels between sand cays and islands (D'Croz et al., 2005). The inner portion of the Archipelago, the Almirante Bay, is a semi-enclosed lagoon that appears to have considerable influence by oceanic conditions via the Bocas del Drago channel, located at the northern end of the Archipelago (Guzmán et al., 2005; D’Croz et al., 2005; Berry et al., 2013). At the southern end of Almirante Bay, is the Bocastorito Bay (also called Dolphin Bay), which is a semi-closed lagoon surrounded by mangrove forest and is considered to be an important nursery ground for the local bottlenose dolphin population and is not influenced by oceanic waters (May-Collado et al., 2012). Southern portions of the Archipelago are influenced by oceanic conditions, via water exchange through the Crawl Cay channel (Fig. 1). The climatic conditions of the Archipelago are highly influenced in terms of rainfall, so dry and rainy seasons are not clearly defined (Guzmán and Guevara, 1998; D’Croz et al., 2005; Guzmán et al., 2005).

There are two major human settlements in the region that are located in Colon Island and Almirante Bay; and other small settlements are scattered throughout the Archipelago. Colon 
Island and Almirante Bay are the main source of chemical and noise pollution in BDT. Human impacts in the Archipelago include: overfishing, pollution, sedimentation, and vessel traffic (Seemann et al., 2013). During the months of high precipitation, rivers like the Changuinola River discharge large amounts of sediment to the semi-closed lagoon of Almirante Bay, which transports sediments from urban areas and banana plantations. Indeed, although mercury also has a natural origin in the Archipelago (Guzmán and Jiménez, 1992; Guzmán and García, 2002), the main industrial source is due to agricultural run-off bananas plantations and vessel traffic associated to their exportation in the Almirante Port (Berry et al., 2013).

\subsection{Tissue samples collection permits}

Tissue samples from fish and bottlenose dolphins from BDT were collected with permission from the Autoridad Nacional del Ambiente in Panama (ANAM; permits SC/A-11-12, SC/A43-12, SC/A-17-14, SE/A-101-16). Methods for remote skin biopsy collection were approved by the Smithsonian Tropical Research Institute IACUC (Institutional Animal Care and Use Committee; permits number 2011-1125-2014-06 and 2016-0203-2019-A2 to Dr. May-Collado). In addition, we included bottlenose dolphin tissue samples collected at La Guajira, located on the northeast portion of the Caribbean coast of Colombia (Fig. 1), to conduct niche trophic comparisons between dolphin populations. The tissue samples were collected under Resolution 1177 Permit for Specimen Collection of Wildlife Biodiversity Non-Commercial Purposes of Scientific Research; authorization granted by National Authority for Environmental Licenses - ANLA in Colombia to Universidad de los Andes.

\subsubsection{Dolphin skin samples collection}

Skin samples from free ranging bottlenose dolphins were collected using a 0.22 caliber modified rifle PAXARMS that fire remote biopsy darts with adjustable pressure (Krützen et al., 2002). Biopsy darts were shot from an approximate distance of 7-10 $\mathrm{m}$ from the research boat to the dolphins (Weller et al., 1997; Krützen et al., 2002; Fruet et al., 2016). This system allows the penetration of the dolphins epidermis leaving behind a small wound (Tezanos- 
Pinto and Baker, 2011), and the effect on dolphins is expected to be low because the polycarbonate body of the dart spreading the impact over a wide area reducing the risk of injury when penetrating the skin (Krützen et al., 2002; Tezanos-Pinto and Baker, 2011; Fruet et al., 2016). Biopsy darting is a useful methodology to sample tissue of bottlenose dolphins from BDT because these dolphins are very evasive to vessels, and this system allows to collect remote samples and identify the individuals simultaneously (Fruet et al., 2016). Therefore, skin biopsies were collected only if the individual dolphin was photo-identified in order to avoid re sampling the same individual dolphin (Krützen et al., 2002). When dolphins were sighted, a skin sample, photograph, and the location of the sighting were recorded. Skin samples were preserved in alcohol $70 \%$ and stored at $-20^{\circ} \mathrm{C}$ (Amos and Hoelzel, 1991) for subsequent laboratory analysis.

\subsubsection{Fish muscle samples collection}

Fish samples were collected from Almirante Bay, Dolphin Bay, and one 'Outermost' area located at the southern part of the Archipelago, Cayo Coral, which is influenced by oceanic conditions (D’Croz et al., 2005; Guzmán et al., 2005; Berry et al., 2013). In Almirante Bay and Dolphin Bay fish traps were used to capture live fish, and samples from the 'Outermost' area were collected by local fishermen using fish nets. Captured live fish were euthanized by immersing them in ice-cold water bath $\left(-4^{\circ} \mathrm{C}\right)$ following Barker et al. (2002) and Blessing et al. (2010) protocols. The samples were later transported to the Bocas del Toro Smithsonian Research Station for further processing. Approximately $400 \mathrm{mg}$ of dorsal white muscle was removed from each specimen and preserved in alcohol $70 \%$ and stored at $-20{ }^{\circ} \mathrm{C}$ for subsequent laboratory analyses.

\subsection{DNA extraction and molecular sexing}

To determine the sex for each individual dolphin for which a skin sample was collected, we extracted DNA from skin samples using the DNeasy kit (QIAGEN, Valencia, CA, USA). Samples were sexed following the protocol proposed by Gilson et al. (1998), conducting multiplex PCR to amplify the male-specific SRY gene and ZFY/ZFX genes of males and 
females as positive controls. Electrophoresis was performed to observe the bands pattern and determine the sex of each individual.

\subsection{Stable Isotope analyses}

Dolphin and fish tissue samples were left on a bench to let alcohol evaporated, then were homogenized, and freeze-dried. Previous to isotopic analyses, $100 \mathrm{mg}$ of sample was washed with $4 \mathrm{ml}$ of cyclohexane for lipids removal (De Niro and Epstein, 1978; Méndez-Fernandez et al., 2012). The sample was maintained at constant agitation by $10 \mathrm{~min}$ and then centrifuged at 4,500 rpm for 5 min to discard supernatant containing lipids (Méndez-Fernandez et al., 2012). The process was repeated three times. Next the samples were dried at $45^{\circ} \mathrm{C}$ in an oven for $48 \mathrm{~h}$. A small portion of the lipid-free sample $(0.2-0.4 \mathrm{mg})$ was weighted in a tin cup to conduct stable isotope analyses with a continuous flow mass spectrometer (ThermoScientific Delta V Advantage) coupled to an elemental analyser (Thermo Scientific Flash EA 1112). The isotopic measurements were expressed in parts per thousand (\%o), using the delta $(\delta)$ unit relative to the deviation from international standard values PeeDee Belemnite Carbonate for $\delta^{13} \mathrm{C}$ and atmospheric $\mathrm{N}_{2}$ for $\delta^{15} \mathrm{~N}$ (Méndez-Fernandez et al., 2012; Marrugo-Negrete et al., 2018). Based on replicate measurements of internal laboratory standards, experimental precision (SD) was $<0.09$ for $\delta^{13} \mathrm{C}$ and $<0.36$ for $\delta^{15} \mathrm{~N}$.

\subsection{Average Trophic Level Calculation}

Following Hobson et al. (2002), the trophic level (TL) for each fish species was calculated according this equation:

$$
\boldsymbol{T} \boldsymbol{L}=T L \text { Reference primary consumer }+\frac{\delta 15 \mathrm{~N} \text { Consumer }-\delta 15 \mathrm{~N} \text { Reference primary consumer }}{\delta 15 \mathrm{~N} \text { Enrichment between } T L}
$$

where ' $T L$ Reference primary consumer' represents the trophic level of the reference primary consumer which was assumed as two $(T L=2)$. The ' $\delta^{15} \mathrm{~N}$ Consumer' is the mean of nitrogen isotope ratio (\%) of the consumer of interest and the ' $\delta^{15} \mathrm{~N}$ Reference primary consumer' 
represents the mean of nitrogen isotope ratio of the reference primary consumer. The ' $\delta{ }^{15} \mathrm{~N}$ Enrichment between $T L^{\prime}$ is the enrichment of $\delta^{15} \mathrm{~N}$ between trophic levels, which was assumed as 3.4\%o because this value represents the most frequent $\delta^{15} \mathrm{~N}$ enrichment factor in aquatic food webs (Lavoie et al., 2013).

\subsection{Isotopic niche width and Bayesian stable isotope mixing model}

To analyze stable isotope data in the context of isotopic niche width, we adopted the metrics based in a Bayesian framework (Stable Isotope Bayesian Ellipses in R: SIBER; Jackson et al., 2011) to compare bottlenose dolphins in BDT and La Guajira. To test the SIBER assumption of a multivariate normal distribution for each group, the R package mvnormtest' was used (Jarek, 2015). The area of the standard ellipse (SEAC), which is an ellipse obtained by Bayesian inference that contains $40 \%$ of the data regardless of sample size and corrected for small sample sizes, was adopted to compare niche width between groups. A Bayesian estimate of the standard ellipse and its area (SEAB) was used to test whether a group ellipse is smaller or larger than the other. The convex hull area (TA), although much more sensitive to sample size, was also employed to compare among groups and their overlap (Layman et al., 2007). All these metrics were calculated using the functions implemented in the package Stable Isotope Bayesian Ellipses (SIBER model) in R v. 3.4.3.

To estimate the proportional contribution of potential local prey sources to the bottlenose dolphin diet in BDT, we conducted a Bayesian stable isotope mixing model (Parnell et al., 2013) (MixSIAR model) using the isotopic ratios of nitrogen and carbon from dolphin's skin samples (consumer tissue) and fish muscle samples (dietary items). Only fish species with three or more specimens collected were considered in the analysis. We used as enrichment factors for $\delta^{13} \mathrm{C}$ and $\delta^{15} \mathrm{~N}$ the values $1.5 \pm 0.5 \%$ and $3 \pm 0.3 \%$, respectively, which were

calculated in a previous study by Fernández et al. (2011) for skin bottlenose dolphin tissue. The Bayesian stable isotope mixing model was run with a Markov Chain Monte Carlo method (chain length 1,000,000) using the MixSIAR package in R v. 3.4.3. (Stock and Semmens, 2016). 


\subsection{Mercury analyses}

Total mercury (THg) concentrations of tissues were determined using a solid sample atomic absorption spectrometer AMA-254 (Advanced Mercury Analyser-254 from Altec@) as described in Bustamante et al. (2006). The THg determination process in this spectrometer is conducted in three phases: 1$)$ a drying phase $(10 \mathrm{~s})$ at $90^{\circ} \mathrm{c}$ to remove water from the freezedried samples; 2) a decomposition phase (150 s) in which a heating process at $750^{\circ} \mathrm{C}$ is carried out to release $\mathrm{Hg}$ from the samples, producing $\mathrm{Hg}$ vapor which is transported toward the surface of a gold amalgamator; and 3) a measuring phase in which the amalgamator is heated to $800^{\circ} \mathrm{C}$ to release the collected $\mathrm{Hg}$ to the spectrophotometer, allowing $\mathrm{Hg}$ detection by atomic absorption. Duplicates of dried, homogenized tissue samples (ranging from 1 to $10 \mathrm{mg}$ ) were analyzed without a chemical pre-treatment to assess mean $\mathrm{THg}$ concentration and SD for each (Aubail et al., 2013; Angel et al., 2018). Measurements were repeated at least two times until haying analytical differences below 10\%. Following Bustamante et al. (2006), the analytical quality of the THg measurements in the AMA-254 was controlled using blanks at the beginning of each analytical session, and running analyses of certified reference material (CRM) TORT-2 (Lobster hepatopancreas, National Research Council of Canada) at the beginning and every ten analyses. The measured concentration for the CRM was $0.264 \pm$ $0.013 \mathrm{ng} \mathrm{mg}^{-1}(\mathrm{n}=50)$ and the recovery was thus $98 \%$. The $\mathrm{THg}$ measurements were showed in $\mathrm{ng} \mathrm{g}^{-1}$ on a dry weight basis (dw) and the detection limit was $0.059 \mathrm{ng}$.

\subsection{Calculation of trophic magnification factors}

Hg biomagnification was evaluated assuming a trophic chain in which bottlenose dolphins are at the top of the food chain, based on the relationship between $\mathrm{THg}$ concentrations with $\delta^{15} \mathrm{~N}$ ratios on both dolphins and fish. We calculated the mean isotopic and $\mathrm{THg}$ composition and its standard deviation in skin samples of bottlenose dolphins, and in muscle samples of potential prey (11 fish species). To evaluate significant correlations between THg with $\delta^{15} \mathrm{~N}$ ratios as evidence of trophic magnification, Shapiro-Wilk test of normality and Bartlett test of homogeneity of variances were used to test the assumptions of parametric tests on data. A log-transformation of $\mathrm{THg}$ data was used to meet these assumptions. Then, Pearson 
correlation was performed to assess this relationship, and linear regression analysis was conducted to quantify trophic Hg magnification (Lavoie et al., 2013). Results for statistical analyses were carried out in R v. 3.4.3. and considered significant at $p$-value level of $<0.05$. Trophic magnification factor $(T M F)$ was assessed using the slope $(\beta)$ of the regression of log$\mathrm{THg}$, which represents the change in THg concentration per unit change in $\delta^{15} \mathrm{~N}$ through the food chain (Fey et al., 2019), in the following equation:

$$
T M F=10^{\beta}
$$

According this model, when $T M F$ value is $>1$ there is evidence for THg accumulation (Nfon et al., 2009). We also evaluated the 'Bioaccumulation factor' $(B A F)$ to assess $\mathrm{Hg}$ accumulation between prey and dolphins, as the ratio of $\mathrm{Hg}$ concentration in consumer (dolphin) to the $\mathrm{Hg}$ concentration prey (fish) (Arnot and Gobas, 2006). This relation was also used to calculate the 'Biotransference factor' $(B T F)$ to evaluate trophic magnification, which provides information on $\mathrm{Hg}$ transference from dwarf round herring (prey) in the $T L=2$ to fish in the $T L=3$ (according to their trophic level calculated here), and to bottlenose dolphin (consumer) as the last trophic level (Strandberg et al., 1998; Wang, 2002; Barwick and Maher, 2003), as follows:

$$
B T F=\frac{\text { Hg concentration in consumer }(\text { dolphin })}{\text { Hg concentration in prey (fish) }}
$$

According this model, when the $B T F$ value is $>1$ there is evidence for positive biomagnification, which means $\mathrm{Hg}$ increases at least three trophic positions in the food web (Strandberg et al., 1998; Barwick and Maher, 2003; Kehrig et al., 2013).

\subsection{Risk assessment}

Dolphin health risk to THg exposure via fish consumption was assessed using a Maximum Allowable Concentration (MAC) analysis based on the reference dose $\left(R f D, \mathrm{ng} \mathrm{g}^{-1} \mathrm{dw}\right)$, and then a risk quotient $(R Q)$ based on this $M A C_{R f d}$ calculated. The $R f D$ provides a conservative risk assessment data as it is derived from toxicity and adjusted values from the no observable 
adverse effect level (NOAEL) values obtained in mammals, and therefore is generally used for assessing risk to human health from exposure to trace elements (Hung et al., 2006). $M A C_{R f d}$ approach allows assessing the maximum $\mathrm{Hg}$ concentration that dolphins can tolerate in their prey without negative health effects, and $R Q$ approach allows to assess the levels of Hg risk for dolphins (Hung et al., 2004; 2006).

To calculate dolphins $\mathrm{Hg}$-intake, fish Hg concentrations were converted from dry weight (dw) to wet weight (ww) using the following equation:

$$
C w=C d(100-\% \mathrm{H}),
$$

where $C w$ and $C d$ represents $d w$ and ww respectively, and $\% \mathrm{H}$ is the humidity percentage which ranges around $80 \%$ for several fish species (Murray and Burt, 1969; Hislop et al., 1991; Payne et al., 1999; Alonso-Fernández and Saborido-Rey, 2012). Next and following Hung et al. (2004; 2006), dolphins Hg-intake was calculated as follows:

$$
H g \text {-Intake }\left(\mathrm{ng} \mathrm{g}^{-1} \mathrm{day}^{-1}\right)=\frac{C F \times I R \times E F \times E D}{B W \times A T}
$$

where $C F$ represents $\mathrm{Hg}$ concentrations in all fish together $\left(\mathrm{ng} \mathrm{g}^{-1} \mathrm{ww}\right)$ which was calculated taking into account the contribution of each item to the dolphin diet according to SIAR model results. The $I R$ is the ingestion rate per day reported for Atlantic bottlenose dolphins ( $\mathrm{kg}^{-} \mathrm{day}^{-}$ ${ }^{1}$ ) based on an average annual food consumption of around 2,000 $\mathrm{kg}$ of fish for adult dolphins (Kastelein et al., 2002). EF is the exposure frequency per day for one year (day year ${ }^{-1}$ ), represented as 365 days assuming BDT dolphins are exposed to $\mathrm{Hg}$ every day for one year (Hung et al., 2004). ED is the exposure duration (years), and assuming life-time $\mathrm{Hg}$ exposure, we used 45 years as estimated life-time for bottlenose dolphins (Jefferson et al., 2002). $B W$ represents the body weight $(\mathrm{kg})$, which is $260 \mathrm{~kg}$ according to the weight of Atlantic bottlenose dolphin individuals that showed a mean annual food consumption of 2,000 kg (Kastelein et al., 2002). Finally, $A T$ is the average time (days) and represents the period in days in which dolphins are exposed to $\mathrm{Hg}$ during life-time. 
According to Hung et al. (2006), when $H g$-Intake is equal to $R f D$, the $C F$ is equal to $M A C_{R f D}$, as follows:

$$
R f D=\frac{M A C_{R f D} \times I R \times E F \times E D}{B W \times A T}
$$

Thus, the RfD calculated in the previous model is used in the following equation to calculate the $M A C_{R f D}$, as follows:

$$
M A C_{R f D}=\frac{R f D \times \mathrm{BW} \times \mathrm{AT}}{I R \times E F \times E D}
$$

To assess $R Q$, we integrated results of exposure and dose-response assessments, using the following equation:

$$
R Q=\frac{\text { Hg concentration in all prey }}{M A C_{R f D}}
$$

\subsection{Statistical comparisons}

The existence of significant differences between isotope ratios $\left(\delta^{13} \mathrm{C}\right.$ and $\left.\delta^{15} \mathrm{~N}\right)$ and $\mathrm{THg}$ measurements in fish among the three main locations within BDT (Almirante Bay, Dolphin Bay, and 'Outermost' area), was evaluated posteriorly using Analysis of variance (ANOVA) and Tukey multi-comparison tests, considering significant at $p$-value level of $<0.05$. Similarly, significant differences at $p$-value level of $<0.05$ in the isotopic values and $\mathrm{THg}$ concentration with dolphins sexes was assessed using ANOVA or Kruskal-Wallis tests separately for each element. All these statistical analyses were performed in R v. 3.4.3. after test assumptions of parametric data using Shapiro-Wilk test of normality and Bartlett test of homogeneity of variances. 


\section{Results}

A total of 175 fish and 37 dolphin tissue samples were analyzed in this study. Figure 1 shows the locations of collection for the 37 dolphin samples. Overall, there were 18 females (16 adults, two juveniles) and 19 males (18 adults, one juvenile). A total of 21 species of fish were collected $(N=223)$, but only 11 species had at minimum of three sub-samples to be included in the analysis $(N=175$; Table 1$)$. Of these 11 species, only dwarf round herring (Jenkinsia lamprotaenia) was found in all sampled main locations: Almirante Bay $(\mathrm{n}=19)$, Dolphin Bay $(\mathrm{n}=15)$, and the 'Outermost' area $(\mathrm{n}=16)$.

\subsection{Mercury and stable isotope of bottlenose dolphins}

The comparison of carbon and nitrogen isotopic signatures between tissue samples of dolphins revealed differences in isotopic niche between populations from BDT and La Guajira (Fig. 2). BDT dolphins showed a broader isotopic signature range than La Guajira dolphins (Fig. 2). The $\delta^{13} \mathrm{C}$ values for BDT dolphins ranged between $-16.40 \%$ and $-9.17 \%$ (mean $=-13.11 \%$ \pm 1.95 ), and the $\delta^{15} \mathrm{~N}$ ranged between 5.76\%o and 12.77\%o (mean $=10.24 \%$ \% \pm 1.48 ) (Fig. 2). In contrast, La Guajira dolphins had $\delta^{13} \mathrm{C}$ values in a shorter range, between $-16.44 \%$ and $-15.26 \%$ (mean $=-15.71 \%$ \pm 0.41 ), and the $\delta^{15} \mathrm{~N}$ also had a shorter range between $10.90 \%$ and $14.85 \%$ (mean $=12.30 \% \pm 1.26$ ) (Fig. 2). Regarding THg values, BDT dolphin values ranged between 94 and 4,627 $\mathrm{ng} \mathrm{g}^{-1} \mathrm{dw}$ (mean $=1,637 \pm 1,387 \mathrm{ng} \mathrm{g}^{-1} \mathrm{dw}$ ) and La Guajira dolphin values ranged between 2,720 and 10,590 $\mathrm{ng} \mathrm{g}^{-1} \mathrm{dw}$ (mean $=5,526 \pm 3,209$ $\mathrm{ng} \mathrm{g}^{-1} \mathrm{dw}$ ) (Fig. 3). Finally, BDT dolphins did not show significant differences in THg or isotopic signatures between males and females (Kruskal-Wallis $\delta^{13} \mathrm{C} H=0.01$, ANOVA $\delta^{15} \mathrm{~N}$ $F=0.38, \log -\mathrm{THg} F=0.004$, all $p>0.50$ ), which means both sexes feed on prey of the same or similar trophic level within the Archipelago. Because dolphins move during the day around the Archipelago, and dolphin were biopsied at various times of the day, we could not assume that the site of sampling was the site where the animals foraged. Therefore, comparisons among the three main locations within BDT were rendered not informative. 
The results of the Bayesian stable isotope mixing model (MixSIAR) diet estimated suggested a high mean contribution of $40 \%$ by striped parrotfish (Scarus iseri) and $24 \%$ by the dwarf round herring (J. lamprotaenia) to the diet of BDT dolphins (Fig. 4). Other prey fish species contributed to less than $4 \%$ to their diet, and the blue runner (Caranx crysos), lane snapper (Lutjanus synagris), and the northern red snapper (Lutjanus campechanus) were the third, fourth and fifth prey items that contributed to their diet (4, 3 and 3\%, respectively). Remaining fish prey species contributed to $2 \%$ to dolphins' diet (Fig. 4).

\section{2. $\mathrm{THg}, \delta^{13} \mathrm{C}$ and $\delta^{15} \mathrm{~N}$ stable isotope values in fish}

The results showed a wide variation of $\mathrm{THg}, \delta^{13} \mathrm{C}$ and $\delta^{15} \mathrm{~N}$ values among the fish prey collected (see Table 1). The striped parrot fish showed the lowest $\mathrm{THg}$ and $\delta^{15} \mathrm{~N}$ values (mean $=77 \pm 14 \mathrm{ng} \mathrm{g}^{-1} \mathrm{dw}$; and mean $=7.35 \pm 1.59 \%$, respectively) while the dwarf round herring showed the lowest $\delta^{13} \mathrm{C}$ values $(-16.85 \%$ o, \pm 1.58$)$. Compared to fish, the dolphins showed the highest $\mathrm{THg}$ concentration (mean $=1,637 \pm 1,387 \mathrm{ng} \mathrm{g}^{-1} \mathrm{dw}$ ) as well the highest $\delta^{15} \mathrm{~N}$ value $($ mean $=10.25 \%$ \pm 1.48$)$.

There were significant differences in the relationship between $\mathrm{THg}$ and isotopic signatures of carbon and nitrogen between locations where dwarf round herring were collected (ANOVA, $\delta^{13} \mathrm{C} F=165.40, \delta^{15} \mathrm{~N} F=26.98$, Log-THg $F=9.58$, all $p<0.05$; Fig. 5B-C).

The relationship between $\delta^{13} \mathrm{C}$ and $\delta^{15} \mathrm{~N}$ appears to indicate that the diet of dwarf round herring in Almirante Bay and Dolphin Bay is based on oceanic and lower trophic level food items $\left(\delta^{13} \mathrm{C}\right.$ mean $=-17.91 \%$ $\pm 0.42,-17.78 \%$ \pm 0.57 , respectively; $\delta^{15} \mathrm{~N}$ mean $=7.90 \%$ \pm 0.38 and $8.45 \%$ \% \pm .44 , respectively), while in 'Outermost' area it is based on coastal but higher trophic level food items $\left(\delta^{13} \mathrm{C}\right.$ mean $=-14.73 \%$ o $\pm 0.71 ; \delta^{15} \mathrm{~N}$ mean $=8.88 \%$ \pm 0.36 ; Fig. 5A). THg showed significant and lower values in dwarf round herring collected in Dolphin Bay in relation to 'Outermost' area and Dolphin Bay (mean $=83 \pm 42 \mathrm{ng} \mathrm{g}^{-1} \mathrm{dw}$, $153 \pm 58 \mathrm{ng} \mathrm{g}^{-1} \mathrm{dw}$, and $196 \pm 193 \mathrm{ng} \mathrm{g}^{-1} \mathrm{dw}$, respectively; $p<0.05$, Tukey's test; Fig. 5BC). 


\section{Trophic relationship, biomagnification between dolphins, and prey and risk assessment of adverse effects}

The estimated relative $T L$ was also assessed for bottlenose dolphins and the fish species described in Table 1. We used the redtail parrotfish (Sparisoma chrysopterum, $\mathrm{n}=2$ ) as the reference primary consumer despite we only collected two specimens, because it showed the lowest $\delta^{15} \mathrm{~N}$ values $\left(\delta^{15} \mathrm{~N}=5.45 \%\right.$ ) due to their herbivorous habits (Luna and Torres, 2018). Bottlenose dolphins and the French grunt (Haemulon flavolineatum) showed the highest $T L$ (3.40) while the striped parrotfish ( $S$. iseri), the yellow fin mojarra (G. cinereus), and the dwarf round herring showed the lowest $T L$ values $(2.56,2.79$, and 2.86 , respectively).

Figure 6 shows the relationship between THg with $\delta^{15} \mathrm{~N}$ for bottlenose dolphins and all fish expected to form the BDT' dolphin food chain. The Pearson's correlation coefficients showed significant positive correlations between THg and $\delta^{15} \mathrm{~N}(r=0.54 ; p<0.05)$, and the $\beta$ coefficient from linear regression showed a magnitude of 0.60 . Using this $\beta$ coefficient in the $T M F$ equation, result showed a value of $3.98(T M F>1)$.

Figure 7 represents a hypothesized trophic chain for BDT dolphins, with dolphins as top predators in the Archipelago, and potential prey located in two trophic positions ( $T L 2$ and 3 ) according to the $T L$ calculated in Table 1. The Figure 7 shows $B A F$ values between members of the trophic chain; values higher than one, are represented by black arrows. To evaluate the biomagnification among three trophic levels $(B T F)$, we conducted comparisons between the dwarf round herring in $T L=2(T L=2.86)$, other fish including the foureye butterflyfish (Chaetodon capistratus), the northern red snapper (L. campechanus), blue runner ( $C$. crysos), the white grunt (Haemulon plumieri), and the French grunt $(H$. flavolineatum) as $T L=3$ ( $T L=3.14-3.41)$, and dolphins as next trophic level (top predator). The dwarf round herring was used as a reference primary consumer in this trophic chain because it is widely distributed in the Archipelago (it was present in the three main locations within BDT) and is known to be part of the diet of several pelagic fish species in the Caribbean (Friedlander and Beets, 1997). The BTF calculated between the dwarf round herring and fish from third $T L$ are presented in blue arrows on Figure 7; all these BTF also showed values higher than one. 
Table 2 summarizes the values used into equations to calculate the risk assessment of bottlenose dolphins in BDT. The table also includes the $R f D$ and $M A C_{R f D}$ values calculated here. $R Q$ analyses based on $M A C_{R f D}$ showed a value of one $(R Q=1.00)$.

\section{Discussion}

This study provides the first description of feeding ecology using stable isotopes and $\mathrm{THg}$ biomagnification process of bottlenose dolphins from the Archipelago of Bocas del Toro (BDT, Panama). Our results support previous findings based on genetic evidence that this bottlenose dolphin population is an 'inshore form' with significant geographical isolation (Barragán-Barrera et al., 2017), and highlights the vulnerability of this population to human activities (May-Collado et al., 2015; Sitar et al., 2016).

\subsection{Stable isotope composition of bottlenose dolphins}

The carbon isotope ratio $\left(\delta^{13} \mathrm{C}\right)$ is an indicator of the feeding habitat of an organism (Newsome et al., 2006; 2010; Graham et al., 2010). In BDT, the range of $\delta^{13} \mathrm{C}$ values $(-16.40$ to $-9.17 \%$ ) indicated that bottlenose dolphins have a wide feeding niche. By contrast, dolphins in La Guajira (Colombia) showed a much narrower range of carbon values and with lower values of $\delta^{13} \mathrm{C}(-16.44$ to $-15.26 \%$ ) (Fig. 2). The differences in isotopic niche wide indicated that dolphin prey species are acquiring carbon by sources unique to each location. La Guajira coast is characterized by considerable seasonal variation in productivity which affects prey availability, and consequently dolphin presence (Gordon, 1967; Müller-Karger et al., 1989; Andrade et al., 2003; Andrade and Barton, 2005; Lonin et al., 2010; Paramo et al., 2011; Farías-Curtidor and Barragán-Barrera et al., 2017; Barragán-Barrera et al., 2019). Bottlenose dolphins in La Guajira do not appear to be resident to the area, and recent genetic findings identify them as 'worldwide distributed form' (Duarte et al., 2018), which do not show residency to inshore areas (Tezanos-Pinto et al., 2009). 
Differences between coastal and oceanic habitat are reflected in their $\delta^{13} \mathrm{C}$ values, with higher values representing coastal habitats and lower values in oceanic habitat (Schell et al., 1998; Burton and Koch, 1999; Das et al., 2003; Newsome et al., 2010). The values of dolphin skin samples at $\mathrm{La}$ Guajira were more depleted in ${ }^{13} \mathrm{C}$ than those reported for the BDT dolphins, but were similar to values reported from other offshore bottlenose dolphins (e.g. DíazGamboa, 2003; Segura et al., 2006). This corroborates that dolphins at La Guajira prefer to forage in oceanic habitats, which is consistent with their genetic designation of the 'worldwide distributed form'. In contrast, the BDT bottlenose dolphins showed $\delta^{13} \mathrm{C}$ values similar to other coastal populations (e.g. Segura et al., 2006; Barros et al., 2010), indicating that they consume prey from coastal areas. The skin stable isotope $\delta^{13} \mathrm{C}$ values also indicate that the BDT dolphins fed on prey with several carbon sources. This region consists of several productive coastal ecosystems including coral reefs, mangroves, and seagrass beds (Guzmán and García, 2002; D’Croz et al., 2005; Guzmán et al., 2005). Coastal primary producers such as macroalgae and seagrasses show elevated $\delta^{13} \mathrm{C}$ values (Peterson and Fry, 1987). Consequently, the mutton snapper (Lutjanus analis) and the yellow fin mojarra (G. cinereus), which can be found in shallow coastal ecosystem (such as coral reefs, mangroves, and seagrass beds), had the highest mean $\delta^{13} \mathrm{C}$ values $(-11.84 \%$ and $-11.85 \%$, respectively) (Allen, 1985; Bussing, 1995). In contrast, the dwarf round herring, which is one of the most common and more widely distributed fish in the Archipelago, showed the lowest $\delta^{13} \mathrm{C}$ value (mean $=-16.85 \%$ ) . This result may be explained by their nocturnal feeding behavior, in which dwarf round herring usually inhabits inshore areas during the day (Friedlander and Beets, 1997), but feed on zooplankton during the night in offshore areas (Radakov and Silva, 1974; Friedlander and Beets, 1997). Dwarf round herrings consume a ${ }^{13} \mathrm{C}$-depleted diet, since offshore primary producers (phytoplankton) have low $\delta^{13} \mathrm{C}$ values, and consequently provide a low carbon oceanic food sources for their coastal predator such a bottlenose dolphins. Additionally, it has been suggested that nutrient inputs via river plume can increase carbon sources within BDT (Seemann et al., 2013). A previous work showed the lowest $\delta^{13} \mathrm{C}$ isotope ratios of the particulate organic carbon in Almirante Bay (mean $=-20.7 \%$ \pm 0.5 ) (Seemann et al., 2013), and the dwarf round herring also showed more depleted ${ }^{13} \mathrm{C}$ values in Almirante Bay than in Dolphin Bay and the 'Outermost' area. Since Almirante Bay is a semi-enclosed lagoon with low nutrient influence from the Changuinola River runoff, and because 
productive marine ecosystems in this area have been affected by human activities (Seemann et al., 2013), low primary production may reflect low $\delta^{13} \mathrm{C}$ values.

The present study revealed that the dwarf round herring is one of the most important prey in the diet of BDT bottlenose dolphins despite that the Archipelago offers a broad array of potential prey. These findings agree with the stomach content of one dead female found in Dolphin Bay, while this study was conducted on July 27, 2012. The female contained a large number of unidentified sardines. Besides the dwarf round herring, the other species that more contribute to the diet of these dolphins is the striped parrotfish. The stable isotope $\delta^{15} \mathrm{~N}$ indicated that the BDT bottlenose dolphins feed on prey at a low trophic level. The dwarf round herring and the striped parrotfish are species that are located at 2.86 and 2.56 trophic level, respectively. In contrast, the $\delta^{15} \mathrm{~N}$ values of La Guajira bottlenose dolphins indicate that they feed on prey at a higher trophic level, suggesting their diet consist primarily of pelagic species.

The great availability of herrings in the Archipelago appears to be an important reliable food source for females and males dolphins in BDT, since no significant differences between isotopic signatures and sex were detected. This predictable prey item may explain why dolphins remain in the area, despite the intensity of interactions with dolphin-watching boats. A study by Kassamali-Fox et al. (2015) found that boats affected the dolphin foraging and social behavior, by switching to avoidance behaviors. The number of boats during interacting predicted the likelihood of these dolphins to return to these behaviors. However, given the availability of herring in the area and despite the presence of vessels, it is likely that dolphins are able to forage on their favorite prey.

\subsection{Hg concentrations}

The BDT dolphins showed lower concentrations of THg in comparison to the dolphins at La Guajira and other bottlenose dolphin populations, such as the Indian River Lagoon and the Everglades in Florida, USA (THg mean $=7,000$ and $\mathrm{THg}$ mean $=9,314 \mathrm{ng} \mathrm{g}^{-1} \mathrm{dw}$, respectively) (Stavros et al., 2007; Damseaux et al., 2017), and the Mediterranean Sea (THg 
$=5,700 \mathrm{ng} \mathrm{g}^{-1} \mathrm{dw}$ ) (Aubail et al., 2013), where also other delphinid species show higher THg concentrations in their skin (e.g. Striped dolphin, Stenella coeruleoalba, THg mean $=3,000$ $\mathrm{ng} \mathrm{g}^{-1} \mathrm{dw}$; Aubail et al., 2013). Nevertheless, THg levels reported here were similar to concentrations reported for bottlenose dolphins in Charleston in South Carolina, USA (THg mean $\left.=1,700 \mathrm{ng} \mathrm{g}^{-1} \mathrm{dw}\right)$ (Stavros et al., 2007), and for other delphinid species in the Mediterranean Sea (e.g. Common dolphin, Delphinus delphis, THg mean $=1,700 \mathrm{ng} \mathrm{g}^{-1} \mathrm{dw}$; Harbour porpoise, Phocoena phocoena, THg mean = 1,600 ng g-1 dw; Aubail et al., 2013) and in Sub-Antarctic waters (e.g. Commerson's dolphin, Cephalorhynchus commersonii, THg mean = 1,380 $\mathrm{ng} \mathrm{g}^{-1} \mathrm{dw}$; Cáceres-Saez et al., 2015) (see Table 3). Many coastal areas are influenced by several anthropogenic activities that may increment the $\mathrm{Hg}$ concentrations in these marine environments and thus on dolphin's prey and subsequently in their tissues (Evans and Crumley, 2005). However, the influence of prey may not be necessarily a reflection of the level of anthropogenic contamination, but differences in prey sources. For example, pelagic fish $\mathrm{Hg}$ concentrations have been shown to increase with increasing median depth of occurrence (Monteiro et al., 1996; Choy et al., 2009), so pelagic prey can reflect higher $\mathrm{Hg}$ concentrations than none polluted coastal areas. Following this, La Guajira dolphins appear to feed on a narrow prey selection items of pelagic habits, resulting in higher concentrations of THg than the coastal bottlenose dolphins of BDT.

Dolphins in BDT feed primarily on prey at low trophic levels with low concentration of $\mathrm{Hg}$. The Hg low concentrations could be also related to the dominance of juvenile fish in the Archipelago, which reflect lower $\mathrm{Hg}$ concentrations compare to bigger ones as a consequence of bioaccumulation of $\mathrm{Hg}$ with age (Boush and Thieleke, 1983; Marrugo-Negrete et al., 2018). The abundance of juvenile fish in areas such as Almirante Bay is a result of dramatic decrease of larger predatory fish due to overfishing (Seemann et al., 2013). Previous works have reported Hg concentrations in corals and sediments in the Archipelago (Guzmán and Jiménez, 1992; Guzmán and García, 2002; Berry et al., 2013; Seemann et al., 2013). Because of their fish diet, dolphins may be bioaccumulating and magnificating THg through their prey, as suggested by the positive significant correlation between $\mathrm{Hg}$ concentrations with $\delta^{15} \mathrm{~N}$. Figure 7 shows the predicted $\mathrm{Hg}$ biotransference from low trophic level prey to the top of the chain where dolphins have the highest THg concentrations among all collected 
specimens. Hg biomagnification processes have been reported in other dolphin populations, for example in the coastal waters of Brazil, the Atlantic spotted dolphin (Stenella frontalis) and the Guiana dolphin (Sotalia guanensis) (Kehrig et al., 2013; 2017). A potential concern about $\mathrm{Hg}$ exposure is that it can be quickly assimilated by their diet and accumulated in dolphin tissues throughout their life (Kehrig et al., 2013) resulting in long-term health risks for dolphins. Dolphin health can be used a proxy of the health of the marine environment and thus as a wakeup call of $\mathrm{Hg}$ exposure to humans (Reif et al., 2015).

\subsection{Health risk}

The results from the $R Q$ based on the $M A C_{R f D}$ indicate there is a potential health risk for both females and males dolphins in BDT due to $\mathrm{Hg}$ bioaccumulation through their diet. According to Hung et al. (2006), an $R Q<1$ do not represent health risk. However, our analysis resulted in a value of $R Q=1$, which indicates a marginal health risk (Hung et al., 2004). Given the conservation status of this population, this result should be taken as an important factor affecting the long-term health condition of this population. As described before, dolphins in BDT show high site fidelity and $\mathrm{Hg}$ bioaccumulates through an animal's lifespan. Considering this, $\mathrm{Hg}$ could be a major health threat for calves, taking account that reproductive females can pass $\mathrm{Hg}$ from their tissues during gestation and through their milk (Frodello et al., 2002), exposing calves to premature mortality (Romero et al., 2016). Furthermore, the Archipelago and particularly Dolphin Bay, where dwarf round herring showed the highest THg concentrations, is surrounded by mangrove forest, an ecosystem that is known to retain $\mathrm{Hg}$ making it available as methyl- $\mathrm{Hg}$ in water sediments to aquatic environments (Miskimmin et al., 1992; Barkay et al., 1997; Kannan et al., 1998; Evans et al., 2001; Silva et al., 2003; Bergamaschi et al., 2012; Dameaux et al., 2017). The high Hg concentrations in dolphins living in South Florida, for example, have been attributed to this intrinsic characteristic of the mangrove forest (Dameaux et al., 2017).

This study provides evidence that the BDT dolphin population is at risk. In addition to being genetically isolated (Barragán-Barrera et al., 2017) and under significant pressure due to boat traffic (May-Collado and Wartzok, 2008, May-Collado and Quiñones-Lebrón, 2014; May- 
Collado et al., 2015), this dolphin population is showing signs of $\mathrm{Hg}$ bioaccumulation. The stable isotope analysis confirmed that this population belongs to the 'inshore form', they consume a wide selection coastal prey items, similar to what has been reported in other coastal dolphin populations (e.g. Segura et al., 2006; Barros et al., 2010). The majority of the dolphin coastal prey items in the BDT are at low trophic level or are juvenile stage, and thus showed low concentrations of $\mathrm{Hg}$. The risk assessment, trophic magnification and biotransference models showed that the $\mathrm{Hg}$ magnification process could be a cause of concern. $\mathrm{Hg}$ accumulates fast in tissues of species of high trophic level, and once in high concentrations, it is toxic, and it may causes cancer (Béland et al., 1993; Martineau et al., 1994), immunotoxicity (Desforges et al., 2016), neurotoxicity (Krey et al., 2015), reduction in antibody concentration (Reif et al., 2015), and damage on the endocrine, hematopoietic, hepatic and renal systems (Bossart, 2011; Schwacke et al., 2002; Correa et al., 2014; Reif et al., 2015). Given the high site fidelity of dolphin to BDT, it is likely that lactating females may be transferring $\mathrm{Hg}$ through their milk to their newborns, and potentially affecting the calf development and survival. Further studies are needed to continue monitoring the $\mathrm{Hg}$ exposure and transfer from mother to calf in this inshore dolphin population, and monitoring $\mathrm{Hg}$ in biota in order to provide some insights on temporal trends in BDT as well.

\section{Acknowledgements}

We thank C. Churlaud and M. Brault-Favrou from the Plateforme Analyses Elémentaires of the LIENSs laboratory for facilitating $\mathrm{Hg}$ analyses, and G. Guillou from the Plateforme Analyses Isotopiques of the LIENSs laboratory for its support in the stable isotope analyses. We thank the STRI Marine Biological Station and Panacetacea for their logistical support. We want to thank to Gabriel Jácome, Rachel Collin, Plinio Góndola, Marlon Smith, Arcadio Castillo, Urania González, Gilberto Murray, Deyvis Gonzalez, Tanyusha Grenald, Cynthia Pena, Celia Mercado, Zurenayka Alain and Orelis Arosemana at the STRI Bocas del Toro Research Station. Special thanks to boat captains Demetrio Georget, Arnulfo Record, Christian Harris, Roger Ayala, Tomás Ayala and fishermen for their support on the smallscale surveys out of Bocas del Toro and La Guajira. We also thank to several people that 
assisted in the field: Shakira Quiñones-Lebrón, Mónica Gamboa-Poveda, Mónica Acosta, Ayshah Kassamali-Fox, Betzi Pérez, José Julio Casas, Lissette Trejos, Joel Sánchez, Whitney Kwiers, Evelin Mosquera, Roberto Santamaría, Julie Tomczyk, Giselle Veve, Cole Tanner, Ashley Sitar, Paula Chávez and Roosevelt Mesa. Samples in Bocas del Toro (Panama) were collected with permission from the Autoridad Nacional del Ambiente (ANAM; permits SC/A-11-12, SC/A-43-12, SC/A-17-14; SE/A-101-16, SE/AO-6-16). Samples in La Guajira (Colombia) were collected under Resolution 1177 of Marco Permit for Specimen Collection of Wildlife Biodiversity Non Commercial Purposes of Scientific Research. This permit was provided by the National Authority for Environmental Licenses (ANLA) to Universidad de los Andes. This study was supported by the Small Grant in Aid of Research from the Society for Marine Mammalogy (DCBB, 2011; 2014; MPHA, 2015). The Sciences Faculty of Universidad de los Andes provided following four Research Grants to DCBB: "Proyecto Semilla - 2013-2 Call for Funding of Research Category: Master and Doctoral students, project 'Genetic structure and diversity of bottlenose dolphins Tursiops truncatus (Montagu, 1821) (Cetacea: Delphinidae) in La Guajira, Colombian Caribbean"” from Universidad de los Andes (DCBB, 2014); the "Proyecto Semilla - 2015-1 Call for Funding of Research Category: Master and Doctoral students, project 'Occurrence, distribution and preliminary genetic status of delphinids in La Guajira, Colombian Caribbean"” (DCBB, 2015); "Proyecto Semilla - 2017-1 Call for Funding of Research Category: Candidates PhD students, project "Mercury concentrations in bottlenose dolphins Tursiops truncatus (Montagu, 1821) (Cetacea: Delphinidae) in Bocas del Toro, Caribbean Coast of Panama" (DCBB, 2016); "Proyecto Semilla - 2018-1 Call for Funding of Research Category: Candidates PhD students, project "Isotopic analyses of bottlenose dolphins' diet in Bocas del Toro: a conservation perspective" (DCBB, 2017). The Rufford Foundation provided five grants for this research: the Rufford Small Grant (DCBB, 2012), the Second Rufford Small Grant (DCBB, 2014), the Booster Grant (DCBB, 2015), the Second Booster Grant (DCBB, 2017), and another Rufford Small Grant (NFC, 2016). The Corporation Center of Excellence in Marine Sciences - CEMarin also supported this study (DCBB, 2018). Funds for PhD studies to DCBB were generously provided by Universidad de los Andes (Biological Sciences Department) and Colciencias. The IUF (Institut Universitaire de France) is acknowledged for 
its support to PB as a Senior Member. The funders had no role in study design, data collection and analysis, decision to publish, or preparation of the manuscript.

\section{References}

Acosta-Pachón, T. A. \& Ortega-García, S. 2019. Trophic interaction between striped marlin and swordfish using different timescales in waters around Baja California Sur, Mexico. Mar. Biol. Res. DOI: 10.1080/17451000.2019.1578377

Allen, G.R. 1985. FAO Species Catalogue. Vol. 6. Snappers of the world. An annotated and illustrated catalogue of Lutjanid species known to date. FAO Fish. Synop. 125(6):208 p. Rome: FAO.

Allen, M. C.; Read, A. J.; Gaudet, J. \& Sayigh, L. S. 2001. Fine-scale habitat selection of foraging bottlenose dolphins Tursiops truncatus near Clearwater, Florida. Mar. Ecol. Prog. Ser. 222: 253-264.

Allen, S. J.; Bejder, L. \& Krützen, M. 2011. Why do Indo-Pacific bottlenose dolphins (Tursiops sp.) carry conch shells (Turbinella sp.) in Shark Bay, Western Australia? Mar. Mamm. Sci. 27(2): 449-454.

Amos, W. \& Hoelzel, A. R. 1991. Long-term preservation of whale skin for DNA analysis. Int. Whal. Comm. Special Issue. 13: 99-104.

Andrade, C.A.; Barton, E. D. \& Mooers, C. N. K. 2003. Evidence for an Eastward Flow along the Central and South American Caribbean Coast. J. Geophys. Res. 108: C6-3185.

Andrade, C. A. \& Barton, E. D. 2005. The Guajira Upwelling System. Cont. Shelf Res. 25: $1003-1022$. 
Angel-Romero P.A.; Barragán-Barrera, D. C.; Botero-Acosta, N.; Riet-Sapriza, F.;

Caballero, S. \& Luna-Acosta, A. 2018. Mercury concentrations in wild humpback whales (Megaptera novaeangliae) sampled in the Colombian Pacific and the Antarctic Peninsula. Int. Whal. Comm. SC/67b/E/09.

Arnot, J. A., \& Gobas, F. A. 2006. A review of bioconcentration factor (BCF) and bioaccumulation factor (BAF) assessments for organic chemicals in aquatic organisms. Environ. Rev. 14(4): 257-297.

Aubail, A.; Méndez-Fernandez, P.; Bustamante, P.; Churlaud, C.; Ferreira, M.; Vingada, J.V. \& Caurant, F. 2013. Use of skin and blubber tissues of small cetaceans to assess the trace element content of internal organs. Mar. Pollut. Bull. 76: 158-169.

Barkay, T.; Gillman, M. \& Turner, R.R. 1997. Effects of dissolved organic carbon and salinity on bioavailability of mercury. Appl. Environ. Microbiol. 63: 4267-4271.

Barker, D.; Allan, G. L.; Rowland, S. J. \& Pickles, J. M. 2002. A Guide to Acceptable Procedures and Practices for Aquaculture and Fisheries Research. Port Stephens, NSW: NSW Fisheries Animal Care and Ethics Committee, Port Stephens Fisheries Centre, New South Wales. 61 pp.

Barragán-Barrera, D. C.; May-Collado, L.J.; Tezanos-Pinto, G.; Islas-Villanueva, V.; Correa-Cárdenas, C.A. \& Caballero. S. 2017. High genetic structure and low mitochondrial diversity in bottlenose dolphins of the Archipelago of Bocas del Toro, Panama: a population at risk? PloS ONE. 12(12): e0189370.

Barragán-Barrera, D. C.; do Amaral, K. B.; Chávez-Carreño, P. A.; Farías-Curtidor, N.; Lancheros-Neva, R.; Botero-Acosta, N.; Bueno, P.; Moreno, I. B.; Bolaños-Jiménez, J.; Bouveret, L.; Castelblanco-Martínez, D. N.; Luksenburg, J. A.; Mellinger, J.; MesaGutiérrez, R.; de Montgolfier, B.; Ramos, E. A.; Ridoux, V. \& Palacios, D. M.. 2019. 
Ecological niche modeling of three species of Stenella dolphins in the Caribbean Basin, with application to the Seaflower Biosphere Reserve. Front. Mar. Sci. 12-Feb-2019.

Barros, N. B.; Ostrom, P. H.; Stricker, C. A. \& Wells, R. S. 2010. Stable isotopes differentiate bottlenose dolphins off west-central Florida. Mar. Mamm. Sci. 26(2): 324336.

Barwick, M. \& Maher, W. 2003. Biotransference and biomagnification of selenium, copper, cadmium, zinc, arsenic and lead in a temperate seagrass ecosystem from Lake Macquarie Estuary, NSW, Australia. Mar. Environ. Res. 56: 471-502.

Bayas-Rea, RdlÁ.; Félix, F. \& Montufar R. 2018. Genetic divergence and fine scale population structure of the common bottlenose dolphin (Tursiops truncatus, Montagu) found in the Gulf of Guayaquil, Ecuador. PeerJ. 6: e4589

Bearhop, S.; Phillips, R. A.; Thompson, D. R.; Waldron, S. \& Furness, R. W. 2000. Variability in mercury concentrations of great skuas Catharacta skua: the influence of colony, diet and trophic status inferred from stable isotope signatures. Mar. Ecol. Prog. Ser. 195: 261-268.

Bearzi, G.; Fortuna, C. \& Reeves, R. 2012. Tursiops truncatus (Mediterranean subpopulation). The IUCN Red List of Threatened Species 2012: e.T16369383A16369386. http://dx.doi.org/10.2305/IUCN.UK.2012-1.RLTS.T16369383A16369386.en. Downloaded on 26 August 2018.

Béland, P.; DeGuise, S.; Girard, C.; Lagacé, A.; Martineau, D.; Michaud, R.; Muir, D. C. G.; Norstrom, R. J.; Pelletier, E.; Ray, S. \& Shugart, L. R. 1993. Toxic compounds and health and reproductive effects in St. Lawrence beluga whales. J. Great Lakes Res. 19(4): 766-775. 
Bergamaschi, B.A.; Krabbenhoft, D.P.; Aiken, G.R.; Patino, E.; Rumbold, D.G.; Orem, W.H. 2012. Tidally driven export of dissolved organic carbon, total mercury, and methylmercury from a mangrove-dominated estuary. Environ. Sci. Technol. 46: 13711378.

Berry, K. L. E.; Seemann, J.; Dellwig, O.; Struck, U.; Wild, C.; \& Leinfelder, R. R. 2013. Sources and spatial distribution of heavy metals in scleractinian coral tissues and sediments from the Bocas del Toro Archipelago, Panama. Environ. Monit. Assess. 185: 9089-9099.

Bisi, T. L.; Dorneles, P.R.; Lailson-Brito, J.; Lepoint, G.; Azevedo, A. F.; Flach, L.; Malm, O.; Das, K. 2013. Trophic relationships and habitat preferences of delphinids from the Southeastern Brazilian coast determined by carbon and nitrogen stable isotope composition. PloS ONE 8(12): e82205.

Blanco, C., Salomón, O., \& Raga, J. A. 2001. Diet of the bottlenose dolphin (Tursiops truncatus) in the Western Mediterranean Sea. J. Mar. Biol. Ass. U.K. 81: 1053-1058.

Blessing, J. J.; Marshall, J. C. \& Balcombe, S. R. 2010. Humane killing of fishes for scientific research: a comparison of two methods. J. Fish Biol. 76 (10): 2571-2577.

Blum, J. D.; Popp, B. N.; Drazen, J. C.; Choy, A. \& Johnson, M. W. 2013. Methylmercury production below the mixed layer in the North Pacific Ocean. Nat. Geosci. 6: 879-884.

Borrell, A.; Aguilar, A.; Tornero, V.; Sequeira, M.; Fernandez, G. \& Alis, S. 2006.

Organochlorine compounds and stable isotopes indicate bottlenose dolphin subpopulation structure around the Iberian Peninsula. Environ. Int. 32(4): 516-523.

Bossart, G. D. 2011. Marine mammals as sentinel species for oceans and human health. Vet. Pathol. 48(3): 676-690. 
Botta, S.; Secchi, E. R.; Rogers, T. L.; Pradoa, J. H. F.; de Lima, R. C.; Carlini, P. \& Negrete, J. 2018. Isotopic niche overlap and partition among three Antarctic seals from the Western Antarctic Peninsula. Deep Sea Res. Part 2. 149: 240-249.

Boush, G. M. \& Thieleke, J. R. 1983. Total mercury content in yellowfin and bigeye tuna. Bull. Environ. Contam. Toxicol. 30: 291-297.

Bowen, W. D. 1997. Role of marine mammals in aquatic ecosystems. Mar. Ecol. Prog. Ser. 158: $267-274$.

Browning, N. E.; Cockcroft, V. G. \& Worthy, G. A. J. 2014. Resource partitioning among South African delphinids. J. Exp. Mar. Biol. Ecol. 457: 15-21.

Burton, R. \& Koch, P. 1999. Isotopic tracking of foraging and long-distance migration in northeastern Pacific pinnipeds. Oecologia. 119: 578-585.

Bussing, W.A. 1995. Gerreidae. Mojarras. P. 1114-1128. In W. Fischer, F. Krupp, W. Schneider, C. Sommer, K.E. Carpenter and V. Niem (eds.) Guia FAO para Identification de Especies para lo Fines de la Pesca. Pacifico Centro-Oriental. 3 Vols. FAO, Rome.

Bustamante, P.; Lahaye, V.; Durnez, C.; Churlaud, C.; Caurant, F. 2006. Total and organic $\mathrm{Hg}$ concentrations in cephalopods from the North Eastern Atlantic waters: Influence of geographical origin and feeding ecology. Sci. Total Environ. 368: 585-596.

Cáceres-Saez, I.; Goodall, R. N. P.; Dellabianca, N. A.; Cappozzo, H. L.; Ribeiro Guevara, S. 2015. The skin of Commerson's dolphins (Cephalorhynchus commersonii) as a biomonitor of mercury and selenium in Subantarctic waters. Chemosphere. 138: 735-743.

Cai, Y.; Rooker, J. R.; Gill, G. A. \& Turner, J. P. 2007. Bioaccumulation of mercury in pelagic fishes from the Northern Gulf of Mexico. Can. J. Fish Aquat. Sci. 64: 458-469. 
Catry, T.; Ramos, J. A.; Le Corre, M., Kojadinovic, J. \& Bustamante, P. 2008. The role of stable isotopes and mercury concentrations to describe seabird foraging ecology in tropical environments. Mar. Biol. 155: 637-647.

Chouvelon, T.; Brach-Papa, C.; Auger, D.; Bodin, N.; Bruzac, S.; Crochet, S.; Degrootec, M.; Hollanda, S. J.; Hubert, C.; Knoery, J.; Munschy, C.; Puech, A.; Rozuel, E.; Thomas, B.; West, W.; Bourjea, J. \& Nikolic. N. 2017. Chemical contaminants (trace metals, persistent organic pollutants) in albacore tuna from western Indian and south-eastern Atlantic Oceans: Trophic influence and potential as tracers of populations. Sci. Total Environ. 596-597: 481-495.

Choy, C. A.; Popp, B. N.; Kaneko, J. J. \& Drazen, J. C. 2009. The influence of depth on mercury levels in pelagic fishes and their prey. PNAS. 106(33): 13865-13869.

Colaco, A.; Bustamante, P.; Fouquet, Y.; Sarradin, P. M. \& Serrao-Santos, R. 2006. Bioaccumulation of $\mathrm{Hg}, \mathrm{Cu}$, and $\mathrm{Zn}$ in the Azores triple junction hydrothermal vent fields food web. Chemosphere. 65: 2260-2267.

Correa, L.; Rea, L. D.; Bentzen, R. \& O'Hara, T. M. 2014. Assessment of mercury and selenium tissular concentrations and total mercury body burden in 6 Steller sea lion pups from the Aleutian Islands. Mar. Pollut. Bull. 82: 175-182.

Cossa, D.; Heimbürger, L. E.; Lannuzel, D.; Rintoul, S. R.; Butler, E. C. V.; Bowie, A. R.; Averty, B.; Watson, R. J. \& Remenyi, T. 2011. Mercury in the Southern Ocean. Geochim. Cosmochim. Acta. 75: 4037-4052.

Cossa, D.; Averty, B. \& Pirrone, N. 2009. The origin of methylmercury in open Mediterranean waters. Limnol. Oceanogr. 54: 837-844.

Damseaux, F.; Kiszka, J. J.; Heithaus, M. R.; Scholl, G.; Eppe, G.; Thom, J. P.; Lewis, J.; Hao, W.; Fontaine, M. C. \& Das, K. 2017. Spatial variation in the accumulation of POPs 
and mercury in bottlenose dolphins of the Lower Florida Keys and the coastal Everglades (South Florida). Environ. Pollut. 220: 577-587.

Das, K.; Lepoint, G.; Leroy, Y. \& Bouquegneau, J. M. 2003. Marine mammals from the southern North Sea: feeding ecology data from $\delta^{13} \mathrm{C}$ and $\delta^{15} \mathrm{~N}$ measurements. Mar. Ecol. Prog. Ser. 263: 287-298.

D’Croz L.; Del Rosario, J. B. \& Góndola, P. 2005. The effect of fresh water runoff on the distribution of dissolved inorganic nutrients and plankton in the Bocas del Toro Archipelago, Caribbean Panama. Caribb. J. Sci. 41(3): 414-429.

De Pierrepont, J. F.; Dubois, B.; Desormonts, S.; Santos, M. B. \& Robin, J. P. 2005. Stomach contents of English Channel cetaceans stranded on the coast of Normandy. J. Mar. Biol. Assoc. U. K. 85(6): 1539-1546.

DeNiro, M.J. \& Epstein, S. 1978. Influence of diet on the distribution of carbon isotopes in animals. Geochim. Cosmochim. Acta. 42(5): 495-506.

DeNiro, M. J. \& Epstein, S. 1981. Influence of diet on the distribution of nitrogen isotopes in animals. Geochim. Cosmochim. Acta. 45(3): 341-351.

Desforges, J-P. W; Sonne, C.; Levin, M.; Siebert, U.; De Guise, S. \& Dietz, R. 2016. Immunotoxic effects of environmental pollutants in marine mammals. Environ. Int. 86: 126-139.

Díaz-Gamboa, R. E. 2003. Diferenciación entre tursiones Tursiops truncatus costeros y oceánicos en el golfo de California por medio de isótopos estables de carbono y nitrógeno. Tesis MSc. Instituto Politécnico Nacional, Centro Interdisciplinario de Ciencias Marinas Departamento de Pesquerías y Biología Marina. 64 pp. 
Duarte-Fajardo, M.A.; Barragán-Barrera, D. C.; Correa-Cárdenas, C. A.; Farías-Curtidor, N.; Pérez-Ortega, B. \& Caballero, S. 2018. Diversidad genética del delfín nariz de botella (Tursiops truncatus) en la Guajira (Caribe colombiano). V Colombian Congress on Zoology. Bogotá, Colombia. December 3 - 7, 2018. Abstract.

Duffy-Echevarria, E. E., Connor, R. C., \& St. Aubin, D. J. 2008. Observations of strandfeeding behavior by bottlenose dolphins (Tursiops truncatus) in Bull Creek, South Carolina. Mar. Mamm. Sci. 24: 202-206.

Evans, D. W.; Crumley, P. H.; Rumbold, D.; Niemczyck, S. \& Laine, K. 2001. Linking Everglades restoration and enhanced freshwater flows to elevated concentrations of mercury in Florida Bay fish. Florida Bay Science Conference, Key Largo. 181-182 p.

Evans, D. W. \& Crumley, P. H. 2005. Mercury in Florida Bay fish: spatial distribution of elevated concentrations and possible linkages to everglades restoration. Bull. Mar. Sci. 77(3): 321-345.

Farías-Curtidor, N.; Barragán-Barrera, D. C.; Jiménez-Pinedo, C.; Palacios, D.; Caicedo, D.; Trujillo, F. \& Caballero, S. 2017. Range extension for the common dolphin (Delphinus sp.) to the Colombian Caribbean, with taxonomic implications from genetic barcoding analysis. PloS ONE. 12(2): e0171000.

Fernández, R.; García-Tiscar, S.; Begoña S., M.; López, A.; Martínez-Cedeira, J. A.; Newton, J. \& Pierce, G. J. 2011. Stable isotope analysis in two sympatric populations of bottlenose dolphins Tursiops truncatus: evidence of resource partitioning?. Mar. Biol. 158(5): 1043-1055.

Fey, P.; Bustamante, P.; Bosserelle, P.; Espiaud, B.; Malaue, A.; Mercader, M.; Wafo, E. \& Letourneur, Y. 2019. Does trophic level drive organic and metallic contamination in coral reef organisms? Sci. Total Environ. 667: 208-221. 
Ford, J. K., Ellis, G. M., Barrett-Lennard, L. G., Morton, A. B., Palm, R. S., \& Balcomb, K. C. 1998. Dietary specialization in two sympatric populations of killer whales (Orcinus orca) in coastal British Columbia and adjacent waters. Can. J. Zool. 76(8): 1456-1471.

Fossi, M. C.; Casini, S.; Caliani, I.; Panti, C.; Marsili, L.; Viarengo, A.; Giangreco, R.; di Sciara, G. N.; Serena, F.; Ouerghi, A. \& Depledge, M. H. 2012. The role of large marine vertebrates in the assessment of the quality of pelagic marine ecosystems. Mar. Environ. Res. 77: 156-158.

Friedlander, A. M. \& Beets, J. P. 1997. Fisheries and life history characteristics of dwarf herring (Jenkinsia lamprotaenia) in the US Virgin Islands. Fish. Res. 31: 61-72.

Frodello, J.P.; Viale, D. \& Marchand, B. 2002. Metal concentrations in the milk and tissues of a nursing Tursiops truncatus female. Mar. Pollut. Bull. 44: 551-576.

Fruet, P. F.; Secchi, E. R.; Daura-Jorge, F.; Vermeulen, E.; Flores, P. A. C.; Simões-Lopes, P. C.; Genoves, R. C.; Laporta, P.; Di Tullio, J. C.; Freitas, T. R.; Rosa, L. D.; Valiati, V. H.; Beheregaray, L. B. \& Möller, L. M. 2014. Remarkably low genetic diversity and strong population structure in common bottlenose dolphins (Tursiops truncatus) from coastal waters of the Southwestern Atlantic Ocean. Conserv. Genet. 15: 879-895.

Fruet, P. F.; Dalla Rosa, L.; Genoves, R. C.; Valiati, V. H.; De Freitas, T. R. O. \& Möller, L. M. 2016. Biopsy darting of common bottlenose dolphins (Tursiops truncatus) in southern Brazil: evaluating effectiveness, short-term responses and wound healing. Lat. Amer. J. Aquat. Mamm. 11(1-2): 121-132.

Gannon, D. \& Waples, D. M. 2004. Diets of coastal bottlenose dolphins from the U. S. Mid-Atlantic coast differ by habitat. Mar. Mamm. Sci. 20(3): 527-545. 
Gilson, A.; Syvanen, M.; Levine, K. \& Banks, J. 1998. Deer gender determination by polymerase chain reaction: validation study and application to tissues, bloodstains and hair forensic samples from California. Calif. Fish Game. 84: 159-169.

Gordon, A. L. 1967. Circulation of the Caribbean Sea. J. Geophys. Res. 72: 6207-6223.

Graham, B. S.; Koch, P. L.; Newsome, S. D.; McMahon, K. W. \& Aurioles, D. 2010. Using isoscapes to trace the movements and foraging behavior of top predators in oceanic ecosystems. (pp. 299-318). In: West J., Bowen G., Dawson T., Tu K. (eds) Isoscapes: Understanding Movement, Pattern, and Process on Earth Through Isotope Mapping. 487 pp.

Guzmán, H. M. \& Jiménez, C. E. 1992. Contamination of coral reefs by heavy metals along the Caribbean coast of Central America (Costa Rica and Panama). Mar. Pollut. Bull. 24: $554-561$.

Guzmán, H. M., \& Guevara, C. A. 1998. Arrecifes coralinos de Bocas del Toro, Panamá: I. Distribución, estructura y estado de conservación de los arrecifes continentales de la Laguna de Chiriquí y la Bahía Almirante. Rev. Biol. Trop. 46(3): 601-623.

Guzmán, H. M \& García, E. M. 2002. Mercury levels in coral reefs along the Caribbean coast of Central America. Mar. Pollut. Bull. 44: 1415-1420.

Guzmán, H. M.; Barnes, P. A. G.; Lovelock, C. E. \& Feller, I. C. 2005. A site description of the CARICOMP mangrove, seagrass and coral reef sites in Bocas del Toro, Panama. Caribb. J. Sci. 41: 430-440.

Hammerschmidt, C. R. \& Bowman, K. L. 2012. Vertical methylmercury distribution in the subtropical North Pacific Ocean. Mar. Chem. 132-133: 77-82. 
Heimbürger, L. E.; Sonke, J. E.; Cossa, D.; Point, D.; Lagane, C.; Laffont, L.; Galfond, B. T.; Nicolaus, M.; Rabe, B. \& van der Loeff, M. R. 2015. Shallow methylmercury production in the marginal sea ice zone of the central Arctic Ocean. Sci. Rep. 5(10318): 16.

Hernandez-Milian, G.; Berrow, S.; Begoña Santos, M.; Reid, D. \& Rogan, E. 2015. Insights into the trophic ecology of bottlenose dolphins (Tursiops truncatus) in Irish Waters. Aquat. Mamm. 41(2): 226-239.

Hobson, K.A.; Fisk, A.; Karnovsky, N.; Holst, M.; Gagnon, J. N. \& Fortier, M. 2002. A stable isotope $\left(\delta^{13} \mathrm{C}, \delta^{15} \mathrm{~N}\right)$ model for the North Water food web: implications for evaluating trophodynamics and the flow of energy and contaminants. Deep Sea Res. Part. 2(49): 5131-5150.

Hooker, S. K., Iverson, S. J., Ostrom, P., \& Smith, S. C. 2001. Diet of northern bottlenose whales inferred from fatty-acid and stable-isotope analyses of biopsy samples. Can. J. Zool. 79(8): 1442-1454.

Hung, C.L.H.; So, M.K.; Connell, D.W.; Fung, C.N.; Lam, M.H.W.; Nicholson, S.; Richardson, B.J. \& Lam, P.K.S. 2004. A preliminary risk assessment of trace elements accumulated in fish to the Indo-Pacific Humpback Dolphin (Sousa chinensis) in the Northwestern waters of Hong Kong. Chemosphere. 56: 643-651.

Hung, C. L. H.; Lau, R. K. F.; Lam, J. C. W.; Jefferson, T. A.; Hung, S. K.; Lam, M. H. W. \& Lam, P. K. S. 2006. Risk assessment of trace elements in the stomach contents of IndoPacific Humpback Dolphins and Finless Porpoises in Hong Kong waters. Chemosphere. 66: $1175-1182$.

Ingram, S. N. \& Rogan, E. 2002. Identifying critical areas and habitat preferences of bottlenose dolphins Tursiops truncatus. Mar. Ecol. Prog. Ser. 244: 247-255. 
Jackson, A.L.; Inger, R.; Parnell, A.C. \& Bearhop, S. 2011. Comparing isotopic niche widths among and within communities: SIBER - Stable Isotope Bayesian Ellipses. J. Anim. Ecol. 80: 595-602.

Jarek, S. 2015. Package "mvnormtest": Normality test for Multivariate Variables. R package version 0.1-9. http://CRAN.R-project.org/package=mvnormtestpp. 1-3.

Jefferson, T.; Webber, M. \& Pitman, R. 2002. Marine Mammals of the World: A Comprehensive Guide to Their Identification. Academic Press. 572 pp.

Jiménez, P.J. \& Alava, J.J. 2015. Strand-feeding by coastal bottlenose dolphins (Tursiops truncatus) in the Gulf of Guayaquil, Ecuador. Lat. Amer. J. Aquat. Mamm. 10(1): 33-37.

Kannan, K.; Blankenship, A.L.; Jones, P.D. \& Giesy, J.P. 2000. Toxicity reference values for the toxic effects of polychlorinated biphenyls to aquatic mammals. Hum. Ecol. Risk Assess. 6: 181-201.

Kassamali-Fox, A.; Christiansen, F.; Quiñones-Lebrón, S.; Rusk, A.; May-Collado, L. J. \& Kaplin, B. 2015. Using Markov chains to model the impacts of the dolphin watching industry on the dolphin community of Dolphin Bay, Bocas del Toro, Panama. Int. Whal. Comm. SC/66a/WW11.

Kastelein, R. A.; Vaughan, N.; Waltonc, S. \& Wiepkemad, P. R. 2002. Food intake and body measurements of Atlantic bottlenose dolphins (Tursiops truncatus) in captivity. Mar. Environ. Res. 53: 199-218.

Kehrig, H. A.; Seixas, T. G.; Malm, O.; Di Beneditto, A. P. M. \& Rezende, C. E. 2013. Mercury and selenium biomagnification in a Brazilian coastal food web using nitrogen stable isotope analysis: a case study in an area under the influence of the Paraiba do Sul River plume. Mar. Pollut. Bull. 75: 283-290. 
Kehrig, H. A.; Baptista, G.; Di Beneditto, A. P. M.; Almeida, M. G.; Rezende, C. E.; Siciliano, S.; de Moura, J. F. \& Moreira, I. 2017. Biomagnificación de mercurio en la cadena trófica del Delfín Moteado del Atlántico (Stenella frontalis), usando el isótopo estable de nitrógeno como marcador ecológico. Rev. Biol. Mar. Oceanogr. 52(2): 233-244.

Krey, A.; Ostertag, S. K. \& Chan, H. M. 2015. Assessment of neurotoxic effects of mercury in beluga whales (Delphinapterus leucas), ringed seals (Pusa hispida), and polar bears (Ursus maritimus) from the Canadian Arctic. Sci. Total Environ. 509-510: 237-247.

Krützen, M.; Barre, L. M.; Möller, L. M.; Heithaus, M. R.; Simms, C. \& Sherwin, W. B. 2002. A biopsy system for small cetaceans: darting success and wound healing in Tursiops spp. Mar. Mamm. Sci. 18: 863-878.

Layman, C.A.; Arrington, D.A.; Montaña, C.G. \& Post, D.M. 2007. Can stable isotope ratios provide for community-wide measures of trophic structure? Ecology. 88: 42-48.

Lavoie, R. A.; Jardine, T. D.; Chumchal, M. M.; Kidd, K. A. \& Campbell, L. M. 2013. Biomagnification of mercury in aquatic food webs: a worldwide meta-analysis. Environ. Sci. Technol. 47: 13385-13394.

Leonzio, C.; Focardi, S. \& Fossi, C. 1992. Heavy metals and selenium in stranded dolphins of the northern Tyrrhenian (NW Mediterranean). Sci. Total Environ. 119: 77-84.

Lonin, S. A.; Hernández, J. L. \& Palacios, D. M. 2010. Atmospheric events disrupting coastal upwelling in the southwestern Caribbean. J. Geophys. Res. 115: C06030.

Loor-Andrade, P.; Galván-Magaña, F.; Elorriaga-Verplancken, F. R.; Polo-Silva, C. \& Delgado-Huertas, A. 2015. Population and individual foraging patterns of two hammerhead sharks using carbon and nitrogen stable isotopes. Rapid Commun. Mass Spectrom. 29(9): $821-829$. 
Luna, S. M. \& Torres, A. G. 2018. Sparisoma chrysopterum (Bloch \& Schneider, 1801)

Redtail parrotfish. In: Froese, R. \& Pauly, D. (eds.) 2018. FishBase. World Wide Web electronic publication. www.fishbase.org (02/2018).

Martineau, D.; De Guise, S.; Fournier, M.; Shugart, L.; Girard, C.; Lagacé, A. \& Béland, P. 1994. Pathology and toxicology of beluga whales from the St. Lawrence Estuary, Quebec, Canada. Past, present and future. Sci. Total Environ. 154(2-3): 201-215.

Marrugo-Negrete, J. L.; Ruiz-Guzmán, J. A. \& Ruiz-Fernández, A. C. 2018.

Biomagnification of Mercury in Fish from Two Gold Mining-Impacted Tropical Marshes in Northern Colombia. Arch. Environ. Contam. Toxicol. 74(1): 121-130.

Mason, R. P. \& Fitzgerald, W. F. 1990. Alkylmercury species in the equatorial Pacific. Nature. 347: 457-459.

May-Collado, L.J. \& Wartzok, D. 2008. A comparison of bottlenose dolphin whistle in the Western Atlantic Ocean: insights on factors promoting whistle variation. J. Mammal. 89: $205-216$.

May-Collado, L. J. \& Quiñones-Lebrón, S. 2014. Dolphin changes in whistle structure with watercraft activity depends on their behavioral state. J. Acoust. Soc. Am. Express Letter. 135: EL193-198.

May-Collado, L. J.; Barragán-Barrera, D. C.; Quiñones-Lebrón, S. G. \& Aquino-Reynoso, W. 2012. Dolphin watching boats impact on habitat use and communication of bottlenose dolphins in Bocas del Toro, Panama during 2004, 2006-2010. Int. Whal. Comm. SC/64/WW2.

May-Collado, L. J.; Quiñones-Lebrón, S. G; Barragán-Barrera, D. C.; Palacios, J. D.; Gamboa-Poveda, M. \& Kassamali-Fox, A. 2015. The Bocas del Toro's dolphin watching 
industry relies on a small community of bottlenose dolphins: implications for management. Int. Whal. Comm. SC/66a/WW10.

Mead, J. G. \& Potter, C. W. 1990. Natural history of bottlenose dolphins along the central Atlantic coast of the United States. In: Leatherwood S, Reeves RR (eds) The bottlenose dolphin. Academic Press, San Diego, USA, pp 165-195.

Mead, J. G., \& Potter, C. W. 1995. Recognizing two populations of the bottlenose dolphin (Tursiups truncatus) off the Atlantic coast of North America: Morphologic and ecologic considerations. IBI Reports. 5:3: 1-44.

Mendes, S.; Newton, J.; Reid, R. J.; Zuur, A. F. \& Pierce, G. J. 2007. Stable carbon and nitrogen isotope ratio profiling of sperm whale teeth reveals ontogenetic movements and trophic ecology. Oecologia. 151: 605-615.

Méndez-Fernandez, P.; Bustamante, P.; Bode, A.; Chouvelon, T.; Ferreira, M.; López, A.; Pierce, G. J.; Begoña S., M.; Spitz, J.; Vingada, J. V. \& Caurant, F. 2012. Foraging ecology of five toothed whale species in the Northwest Iberian Peninsula, inferred using carbon and nitrogen isotope ratios. J. Exp. Mar. Biol. Ecol. 413: 150-158.

Miskimmin, B.M.; Rudd, J.W.M. \& Kelly, C.A. 1992. Influence of dissolved organic carbon, $\mathrm{pH}$, and microbial respiration rates on mercury methylation and demethylation in lake water. Can. J. Fish Aquat. Sci. 49: 17-22.

Milmann, L.; Danilewicz, D.; Machado, R.; Santos, R.A. \& Ott, P.H. 2016. Feeding ecology of the common bottlenose dolphin, Tursiops truncatus, in southern Brazil: analyzing its prey and the potential overlap with fisheries. Braz. J. Oceanogr. 64(4): 415422. 
Monteiro, L. R.; Costa, V.; Furness, R. W. \& Santos, R. S. 1996. Mercury concentrations in prey fish indicate enhanced bioaccumulation in mesopelagic environments. Mar. Eco. Prog. Ser. 141: 21-25.

Moura, J. F.; Tavares, D. C.; Secco, H. K. C. \& Siciliano, S. 2016 Bottlenose dolphins (Tursiops truncatus, Montagu 1821) in central-northern coast of Rio de Janeiro State, Brazil: stranding patterns and insights into feeding habits. Lat. Amer. J. Aquat. Mamm. 11(1-2): 191-198.

Müller-Karger, F. E.; McClain, C. R.; Fisher, T. R.; Esaias, W. E. \& Varela, R. 1989. Pigment distribution in the Caribbean Sea: Observations from space. Prog. Oceanogr. 23: $23-64$.

Newsome, S. D.; Martinez del Rio, C.; Bearhop, S. \& Phillips, D. L. 2006. A niche for isotopic ecology. Front. Ecol. Environ. 5(8): 429-436.

Newsome, S. D.; Clementz, M. T. \& Koch, P. L. 2010. Using stable isotope biogeochemistry to study marine mammal ecology. Mar. Mamm. Sci. 26(3): 509-572.

Paramo, J.; Correa, M. \& Núñez, S. 2011. Evidencias de desacople físico-biológico en el sistema de surgencia en La Guajira, Caribe colombiano. Rev. Biol. Mar. Oceanogr. 46(3): 421-430.

Parnell, A. C.; Phillips, D. L.; Bearhop, S.; Semmens, B. X.; Ward, E. J.; Moore, J. W.; Jackson, A. L.; Grey, J.; Kelly, D. J. \& Inger, R. 2013. Bayesian stable isotope mixing models. Environmetrics. 24(6): 387-399.

Parsons, K. M.; Durban, J. W.; Claridge, D. E.; Herzing, D. L.; Balcomb, K. C. \& Noble, L. R. 2006. Population genetic structure of coastal bottlenose dolphins (Tursiops truncatus) in the Northern Bahamas. Mar. Mamm. Sci. 22: 276-298. 
Peterson, B. J. \& Fry, B. 1987. Stable isotopes in ecosystem studies. Ann. Rev. Ecol. Syst. 18: $293-320$.

Polo-Silva, C.; Galván-Magaña, F. \& Delgado H., A. 2012. Trophic inferences of blue shark (Prionace glauca) in the Mexican Pacific from stable isotope analysis in teeth. Rapid Commun. Mass Spectrom. 26(14): 1631-1638.

Polo-Silva, C.; Newsome, S. D.; Galván-Magaña, F.; Grijalba-Bendeck, M. \& A. SanjuanMuñoz. 2013. Trophic shift in the diet of the pelagic thresher shark based on stomach contents and stable isotope analyses. Mar. Biol. Res. 9(10): 958-971.

Power, M.; Klein, G. M.; Guiguer, K. R. R. A. \& Kwan, M. K. H. 2002. Mercury accumulation in the fish community of a sub-Arctic lake in relation to trophic position and carbon sources. J. Appl. Ecol. 39: 819-830.

Radakov, D.V. \& Silva, A. 1974. Some characteristics of the schooling behavior of Jenkinsia lamprotaenia. J. Ichthyol. 14(2): 283-286.

Reeves, R.; Stewart, B. S.; Clapham, P. J. \& Powell, J. A. 2008. Guide to Marine Mammals of the world ( $2^{\text {nd }}$ ed.). New York, USA: National Audubon Society.

Reif, J. S.; Schaefer, A. M. \& Bossart, G. D. 2015. Atlantic bottlenose dolphins (Tursiops truncatus) as a sentinel for exposure to mercury in humans: closing the loop. Vet. Sci. 2: 407-422.

Rivers, J. B.; Pearson, J. E. \& Shultz, C. D. 1972. Total and organic mercury in marine fish. Bull. Environ. Contam. Toxicol. 8: 257-266.

Riccialdelli, L.; Newsome, S. D.; Fogel, M. L. \& Goodall, R. N. P. 2010. Isotopic assessment of prey and habitat preferences of a cetacean community in the southwestern South Atlantic Ocean. Mar. Ecol. Prog. Ser. 418: 235-248. 
Roditi-Elasar, M.; Karem, D.; Hornung, H.; Kress, N.; Shoham-Frider, E.; Goffman, O. \& Spanier, E. 2003. Heavy metal levels in bottlenose and striped dolphins off the Mediterranean coast of Israel. Mar. Pollut. Bull. 46: 503-512.

Romero, M. B.; Polizzi, P.; Chiodi, L.; Das, K. \& Gerpe, M. 2016. The role of metallothioneins, selenium and transfer to offspring in mercury detoxification in Franciscana dolphins (Pontoporia blainvillei). Mar. Pollut. Bull. 109(1): 650-654.

Rossman, S.; Ostrom, P. H.; Stolen, M.; Barros, N. B.; Gandhi, H.; Stricker, C. A. \& Wells, R. S. 2015. Individual specialization in the foraging habits of female bottlenose dolphins living in a trophically diverse and habitat rich estuary. Oecologia 178(2): 415-425.

Samarra, F. I. P.; Vighi, M.; Aguilar, A. \& Víkingsson, G. A. 2017. Intra-population variation in isotopic niche in herring-eating killer whales off Iceland. Mar. Ecol. Prog. Ser. 564: 199-210.

Santos, M. B.; Fernandez, R.; Lopez, A.; Martinez, J. A. \& Pierce, G. J. 2007. Variability in the diet of bottlenose dolphin, Tursiops truncatus, in Galician waters, northwestern Spain, 1990-2005. J. Mar. Biol. Assoc. U.K. 87(1): 231-241.

Schell, D.; Barnett, B. \& Vinette, K. 1998. Carbon and nitrogen isotope ratios in zooplankton of the Bering, Chukchi and Beaufort Seas. Mar. Ecol. Prog. Ser. 162: 11-23.

Schwacke, L. H.; Voit, E. O.; Hansen, L. J.; Wells, R. S.; Mitchum, G. B.; Hohn, A. A, \& Fair, P. A. 2002. Probabilistic risk assessment of reproductive effects of polychlorinated biphenyls on bottlenose dolphins (Tursiops truncatus) from the Southeast United States Coast. Environ. Toxicol. Chem. 21(12): 2752-2764. 
Seemann, J.; González, C.T.; Carballo-Bolaños, R.; Berry, K.; Heiss, G.A.; Struck, U. \& Leinfelder, R.R. 2013. Assessing the ecological effects of human impacts on coral reefs in Bocas del Toro, Panama. Environ. Monit. Assess. 186: 1747-1763.

Segura, I.; Rocha-Olivares, A.; Flores-Ramírez, S. \& Rojas-Bracho, L. 2006. Conservation implications of the genetic and ecological distinction of Tursiops truncatus ecotypes in the Gulf of California. Biol. Conserv. 133: 336-346.

Sellas, A. B.; Wells, R. S. \& Rosel, P. E. 2005. Mitochondrial and nuclear DNA analyses reveal fine scale geographic structure in bottlenose dolphins (Tursiops truncatus) in the Gulf of Mexico. Conserv. Genet. 6: 715-728.

Shoham-Frider, E.; Goffman, O.; Harlavan, Y.; Kress, N.; Morick, D.; Roditi-Elasar, M.; Shefer, E. \& Keremb, D. 2016. Trace elements in striped dolphins (Stenella coeruleoalba) from the Eastern Mediterranean: A 10-years perspective. Mar. Pollut. Bull. 109: 624-632.

Silva, L. F. F.; Machado, W.; Lisboa Filho, S. D. \& Lacerda, L. D. 2003. Mercury accumulation in sediments of a mangrove ecosystem in SE Brazil. Water. Air. Soil Pollut. 145: 67-77.

Sitar, A.; May-Collado, L. J.; Wright, A. J.; Peters-Burton, E.; Rockwood, L.; Parsons, E. C. M. 2016. Boat operators in Bocas del Toro, Panama display low levels of compliance with national whale-watching regulations. Mar. Pol. 68: 221-228.

Smolker, R.; Richards, A.; Connor, R. Mann, J. \& Berggren, P. 1997. Sponge Carrying by Dolphins (Delphinidae, Tursiops sp.): A Foraging Specialization Involving Tool Use? Ethology. 103(6): 454-465.

Spitz, J.; Rousseau, Y. \& Ridoux, V. 2006. Diet overlap between harbour porpoise and bottlenose dolphin: An argument in favour of interference competition for food?. Estuar. Coast. Shelf Sci. 70(1-2): 259-270. 
Stavros, H. C. W.; Bossart, G. D.; Hulsey, T. C. \& Fair, P. A. 2007. Trace element concentrations in skin of free-ranging bottlenose dolphins (Tursiops truncatus) from the southeast Atlantic coast. Sci. Total Environ. 388: 300-315.

Stock, B. C. \& Semmens, B. X. 2016. MixSIAR GUI User Manual. Version 3.1. https://github.com/brianstock/MixSIAR/.

Strandberg, B.; Bandh, C.; van Bavel, B.; Bergqvist, P. A.; Broman, D.; Näf, C.; Pettersen, H. \& Rappe, C. 1998. Concentrations, biomagnification and spatial variation of organochlorine compounds in a pelagic food web in the northern part of the Baltic Sea. Sci. Total Environ. 217(1-2): 143-154.

Strom, D. G. \&. Graves, G. A. 1995. A comparison of mercury in estuarine fish between Florida Bay and the Indian River Lagoon. Ecosystem Management Report. Florida Department of Environmental Protection, Port St. Lucie. 34 p.

Sunderland, E. M.; Krabbenhoft, D. P.; Moreau, J. W.; Strode, S. A. \& Landing, W. M. 2009. Mercury sources, distribution, and bioavailability in the North Pacific Ocean: Insights from data and models. Glob. Biogeochem. Cycles. 23(2): GB2010.

Tezanos-Pinto, G.; Scott B., C.; Russell, K.; Martien, K.; Baird, R. W.; Hutt, A.; Stone, G.; Mignucci-Giannoni, A.; Caballero, S.; Endo, T.; Lavery, S.; Oremus, M.; Olavarría, C. \& Garrigue, C. 2009. A worldwide perspective on the population structure and genetic diversity of bottlenose dolphins (Tursiops truncatus) in New Zealand. J. Hered. 100(1): 1124.

Tezanos-Pinto, G. \& Baker, C. S. 2011. Short-term reactions and long-term responses of bottlenose dolphins (Tursiops truncatus) to remote biopsy. NZJ Mar. Freshw. Res. 1: 1-17. 
Thompson, D. R.; Bearhop, S.; Speakman, J. R. \& Furness, R. W. 1998. Feathers as a means of monitoring mercury in seabirds: insights from stable isotope analysis. Environ. Pollut. 101: 193-200.

Vermeulen, E. \& Bräger, S. 2015. Demographics of the Disappearing Bottlenose Dolphin in Argentina: A Common Species on Its Way Out?. PloS ONE. 10(3): e0119182.

Van Waerebeek, K.; Reyes, J. C.; Read, A. J. \& McKinnon, J. S. 1990. Preliminary observations of bottlenose dolphins from the Pacific coast of South America. Pp 143-54. In: S. Leatherwood and R.R. Reeves (eds). The Bottlenose Dolphin. Academic Press, San Diego. 653 pp.

Walker, J. L.; Potter, C. W. \& Macko, S. A. 1999. The diets of modern and historic bottlenose dolphin populations reflected through stable isotopes. Mar. Mamm.Sci. 15(2): $335-350$.

Weller, D. W.; Cockcroft, V. G.; Würsig, B.; Lynn, S. K. \& Fertl, D. 1997. Behavioral responses of bottlenose dolphins to remote biopsy sampling and observations of surgical biopsy wound healing. Aquat. Mamm. 23(1): 49-58.

Wells, R.S.; Rhinehart, H.L.; Hansen, L.J.; Sweeny, J.C.; Townsend, F.I.; Stone, R.; Casper, D. R.; Scott, M. D.; Hohn, A. A. \& Rowles, T. K. 2004. Bottlenose dolphins as marine ecosystem sentinels: developing a health monitoring system. Ecohealth. 1: 246-254.

Wiener, J. G.; Krabbenhoft, D. P.; Heinz, G. H.; Scheuhammer, A.M. 2003. Ecotoxicology of mercury. Handbook of ecotoxicology. 2: 409-463.

Woshner, V.; Knott, K.; Wells, R.; Willetto, C.; Swor, R. \& O’Hara, T. 2008. Mercury and selenium blood and epidermis of bottlenose dolphins (Tursiops truncatus) from Sarasota Bay, FL: Interaction and relevance to life history and hematologic parameters. Ecohealth. 5: 360-370. 


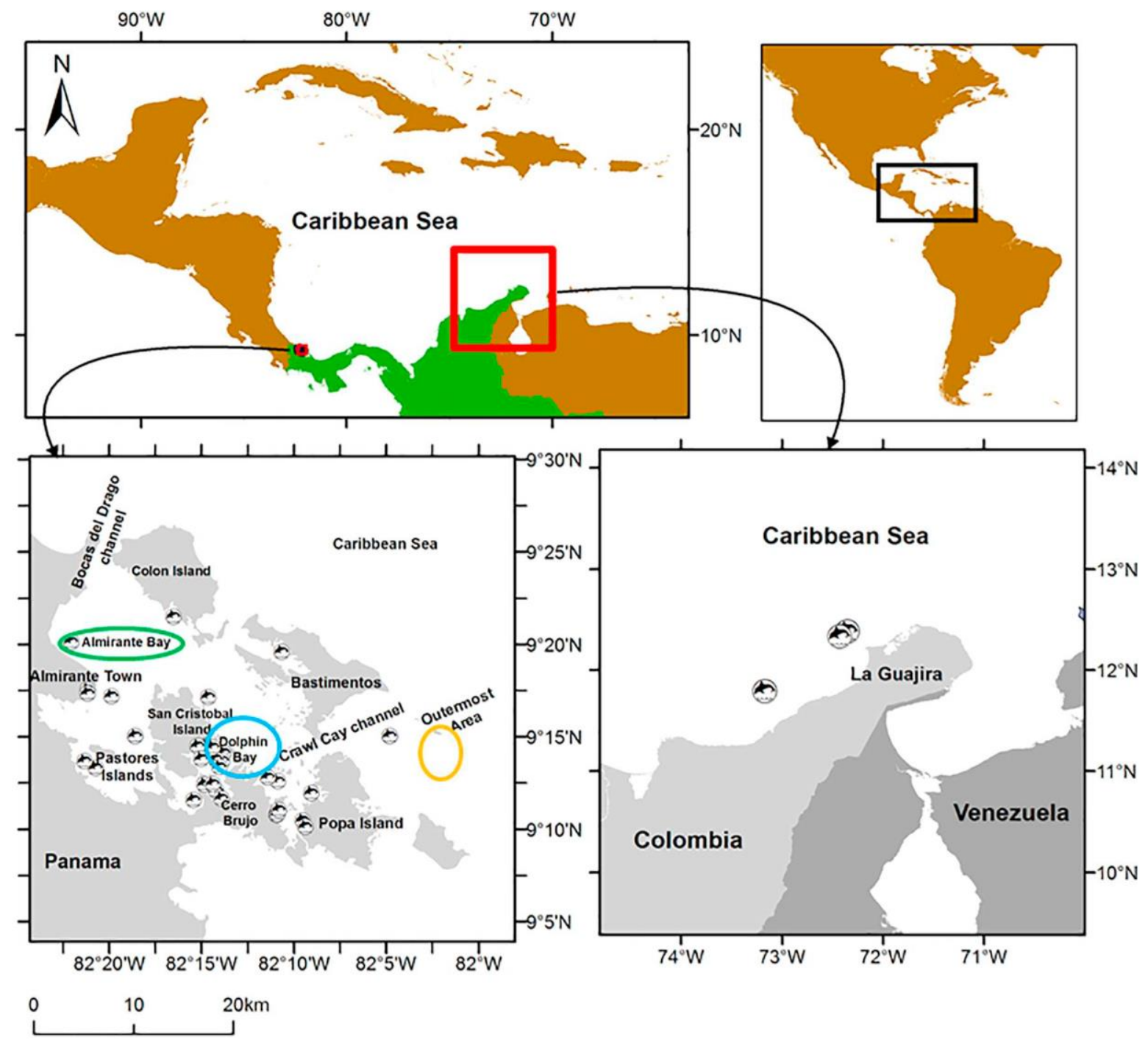

Fig. 1. Location of common bottlenose dolphins (Tursiops truncatus) sampled in Bocas del Toro, Panama and La Guajira, Colombia in the Caribbean. The map of Bocas del Toro bottom left shows the three main locations where fish were collected, including Almirante Bay (green), Dolphin Bay (blue), and the 'Outermost' area (yellow). 


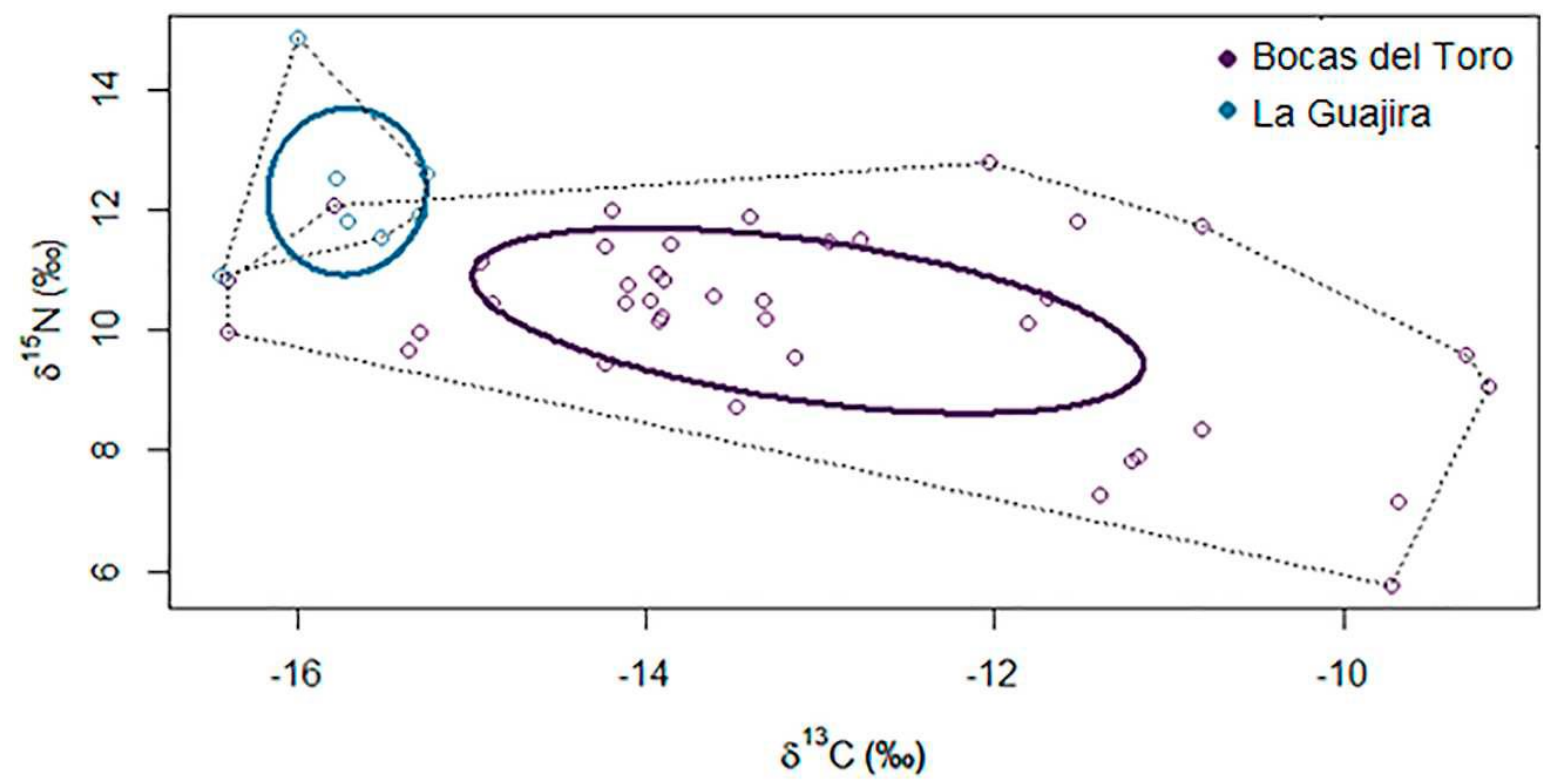

Fig. 2. Carbon $\left(\delta^{13} \mathrm{C}\right)$ and nitrogen $\left(\delta^{15} \mathrm{~N}\right)$ isotope values (\%o) for Bocas del Toro, Panama (purple) and La Guajira, Colombia (blue) bottlenose dolphins (Tursiops truncatus) representing the niche trophic widths. Solid lines indicate standard ellipses areas corrected for small sample sizes (SEAc) and the convex hull area (TA) by dotted line. 

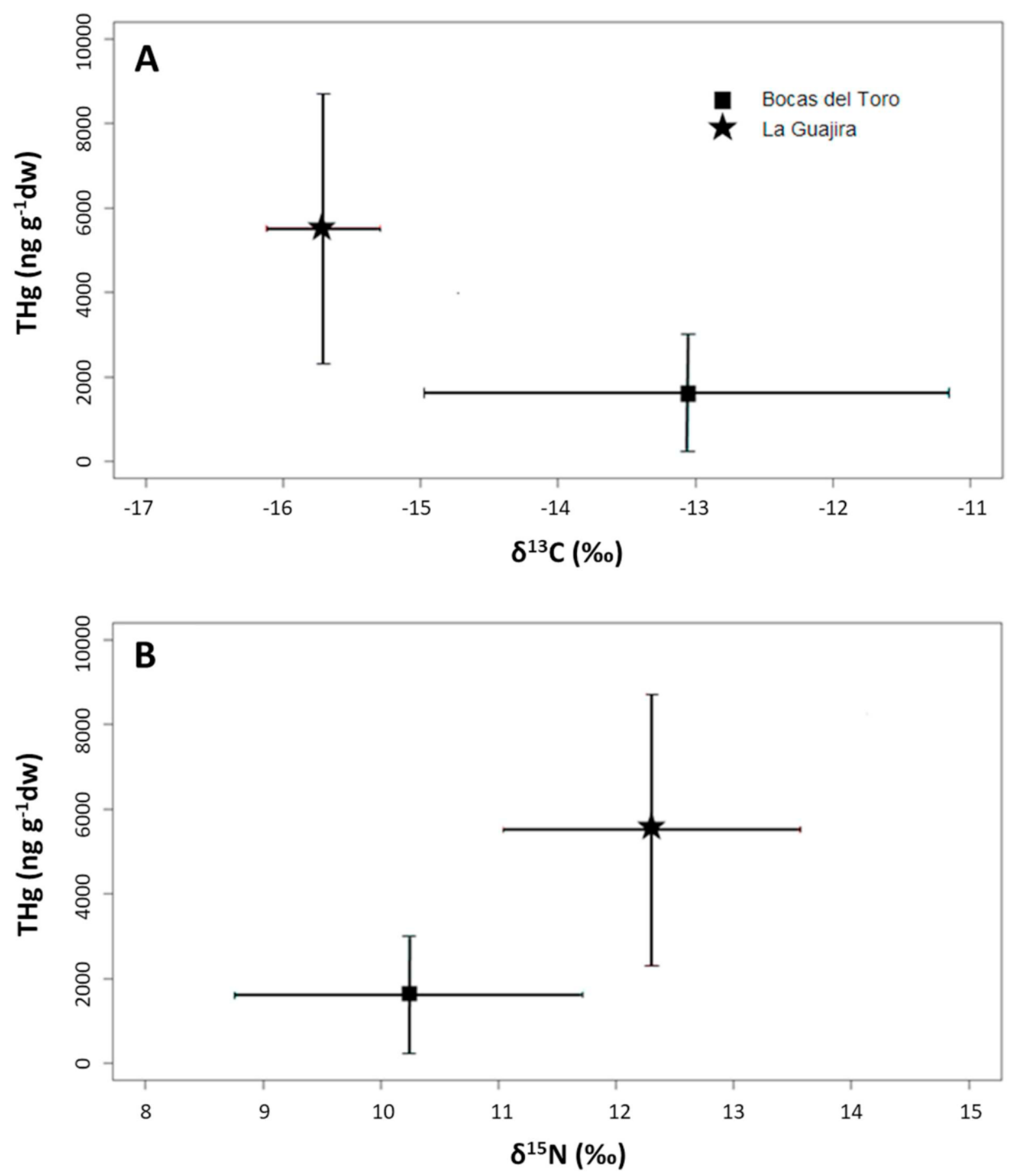

Fig. 3. Stable isotope values (\%) in relation to total mercury $\mathrm{THg}\left(\mathrm{ng} \mathrm{g}^{-1} \mathrm{dw}\right)$ of bottlenose dolphins (Tursiops truncatus) in Bocas del Toro, Panama (star) and La Guajira, Colombia (square). Carbon $\left(\mathrm{A}, \delta^{13} \mathrm{C}\right)$ and nitrogen $\left(\mathrm{B}, \delta^{15} \mathrm{~N}\right)$. 


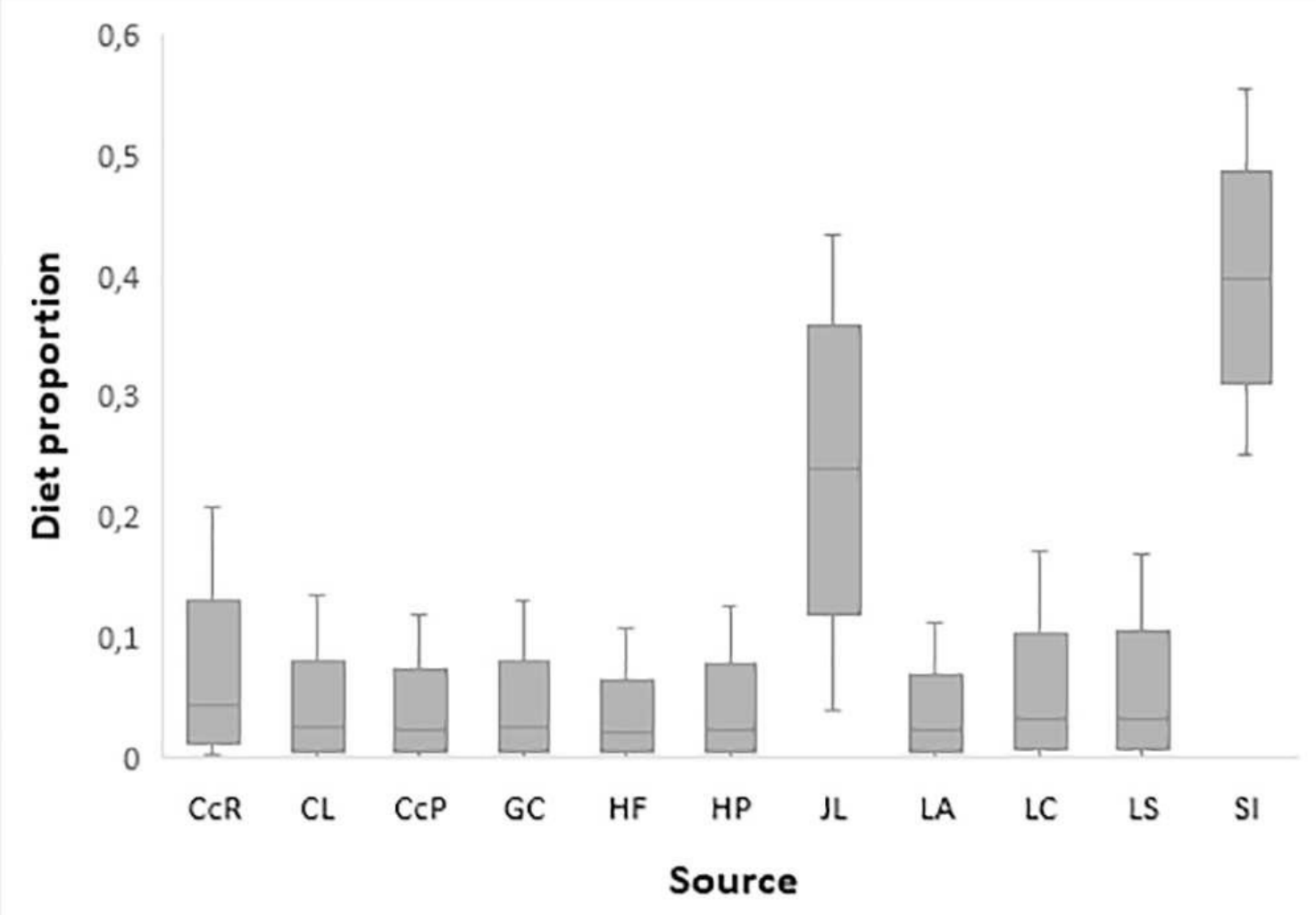

Fig. 4. Posterior estimates of bottlenose dolphins (Tursiops truncatus) diet in Bocas del Toro, Panama according to MixSIAR Bayesian stable isotope mixing model. Median diet proportions (\%) of each source are: blue runner Caranx crysos (CcR, 4.4\%), horse-eye jack Caranx latus (CL, 2.6\%), foureye butterflyfish Chaetodon capistratus (CcP, 2.4\%), yellow fin mojarra Gerres cinereus (GC, 2.6\%), French grunt Haemulon flavolineatum (HF, 2.2\%), white grunt Haemulon plumieri (HP, 2.4\%), dwarf round herring Jenkinsia lamprotaenia (JL, 23.9\%), mutton snapper Lutjanus analis (LA 2.4\%), northern red snapper Lutjanus campechanus (LC, 3.3\%), lane snapper Lutjanus synagris (LS, 3.3\%), and striped parrotfish Scarus iseri (SI, 39.7\%). 

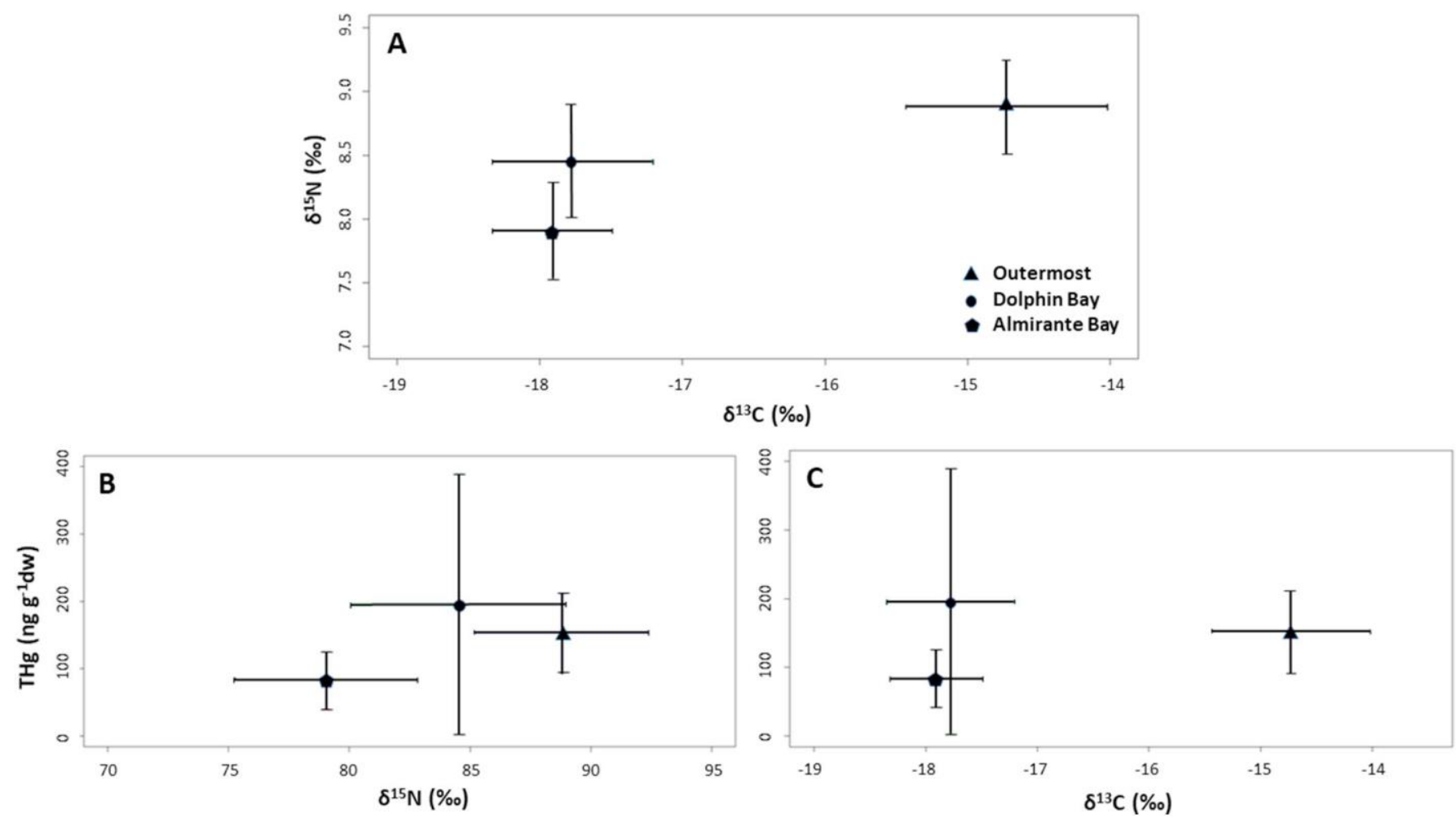

Fig. 5. Mean \pm SD carbon and nitrogen isotopic signatures (\%o) and $\mathrm{THg}$ concentrations ( $\mathrm{ng} \mathrm{g}^{-1} \mathrm{dw}$ ) of dwarf round herring from three main locations within the Bocas del Toro Archipelago, Panama (triangle: Almirante Bay, circle: Dolphin Bay, square: 'Outermost' area). In (A) is represented relationship between carbon $\left(\delta^{13} \mathrm{C}\right)$ and nitrogen $\left(\delta^{15} \mathrm{~N}\right)$ stable isotope values; in $(\mathrm{B})$ and $(\mathrm{C})$ is represented relationship between $\mathrm{THg}$ with $\delta^{13} \mathrm{C}$ and $\delta^{15} \mathrm{~N}$ values, respectively. 


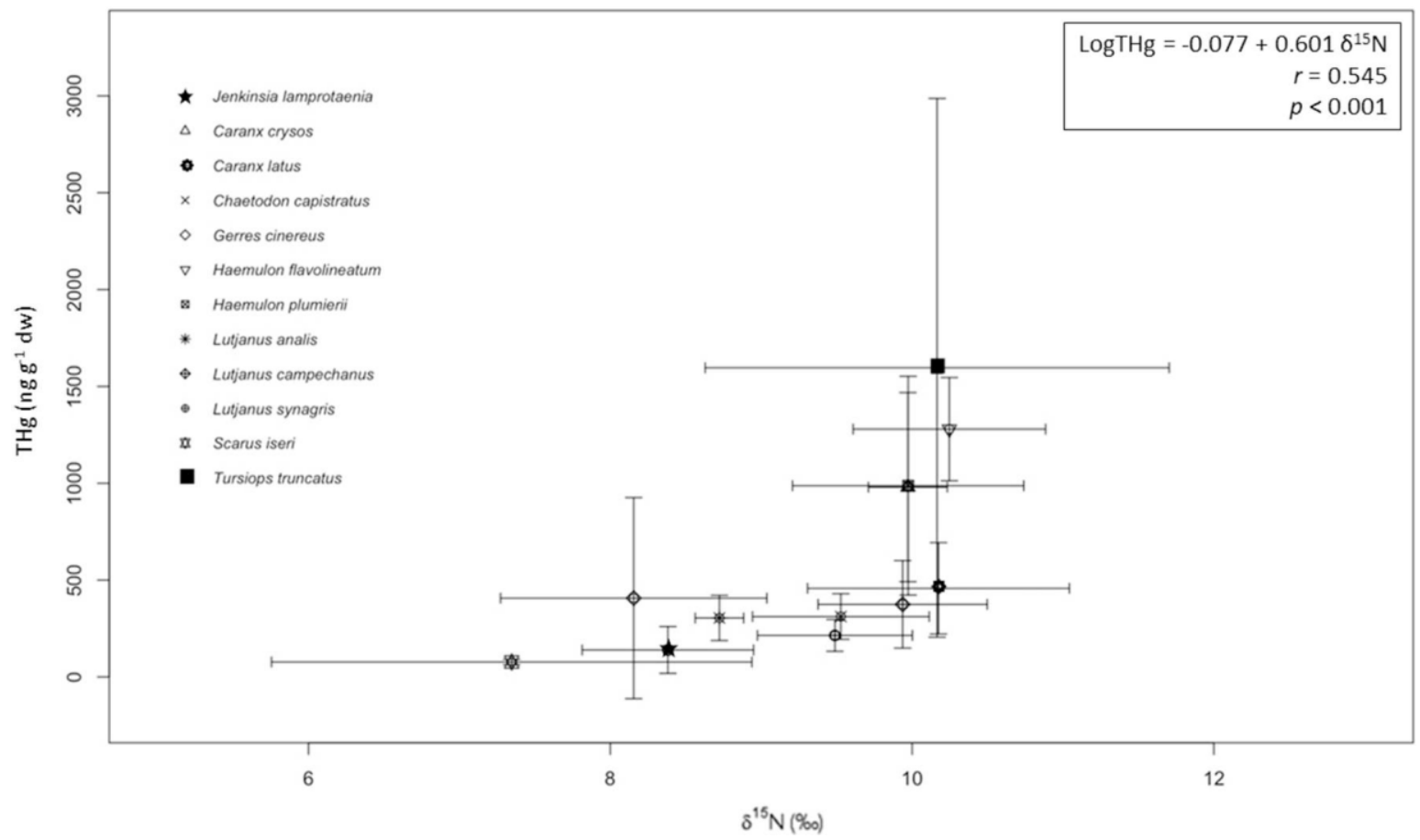

Fig. 6. Relationship between nitrogen isotopic ratio $\left(\delta^{15} \mathrm{~N}\right.$ in $\%$ o), and $\mathrm{THg}$ concentrations (ng g $\mathrm{g}^{-1} \mathrm{dw}$ ) in bottlenose dolphins (Tursiops truncatus) and 11 fish species that compose a trophic chain in Bocas del Toro, Panama. 


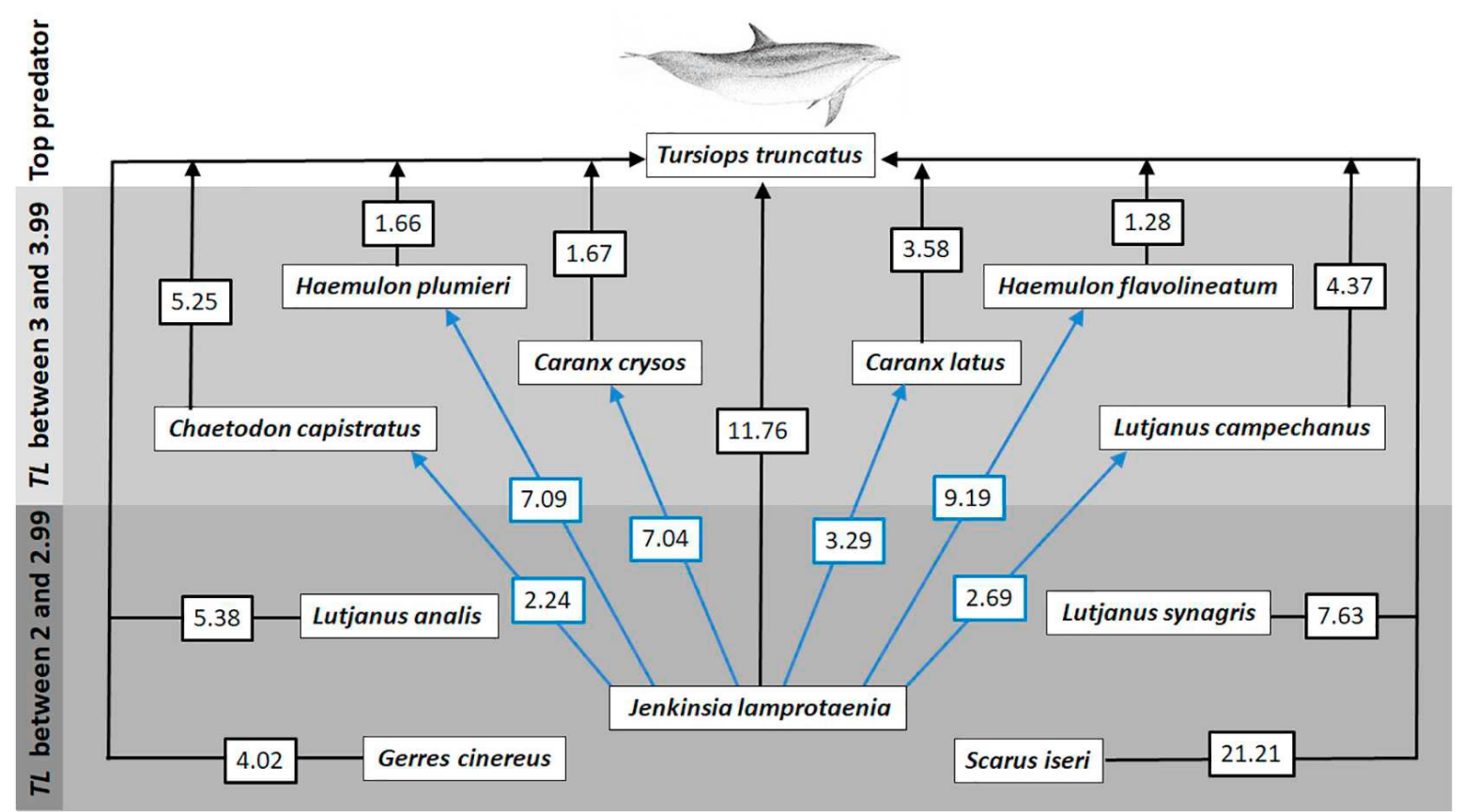

Fig. 7. Bioaccumulation factor $(B A F)$ and biotransference factor $(B T F)$ of $\mathrm{THg}$ through a trophic chain representation in Bocas del Toro, Panama with bottlenose dolphins (Tursiops truncatus) as top predator. Indicated numbers on black arrows refer to $B A T$ among all fish and bottlenose dolphins. Indicated number on blue arrows refer to BFT between the dwarf round herring (Jenkinsia lamprotaenia) as prey in second trophic level $(T L=2)$, fish from third trophic level $(T L=3)$ and dolphins as last trophic level. 
Table 1. Stable isotope ratios $\left(\delta^{13} \mathrm{C}\right.$ and $\delta^{15} \mathrm{~N}$ in \%o), total mercury (THg in ng g ${ }^{-1} \mathrm{dw}$ ) concentration and trophic level (TL) of bottlenose dolphins, Tursiops truncatus, and potential prey fish species collected in Bocas del Toro, Panama.

\begin{tabular}{|c|c|c|c|c|c|c|c|}
\hline Species & Common name & $N$ & $\begin{array}{l}\delta^{13} \mathrm{C} \\
\text { Mean } \pm \mathrm{SD}\end{array}$ & $\begin{array}{l}\delta^{15} \mathrm{~N} \\
\text { Mean } \pm \mathrm{SD}\end{array}$ & $\begin{array}{l}\text { THg } \\
\text { Min-max }\end{array}$ & $\begin{array}{l}\text { THg } \\
\text { Mean } \pm \mathrm{SD}\end{array}$ & $T L$ \\
\hline Caranx crysos & Blue runner & 10 & $-16.21 \pm 0.27$ & $9.97 \pm 0.26$ & $253-1813$ & $980 \pm 488$ & 3.33 \\
\hline Caranx latus & Horse-eye jack & 48 & $-14.64 \pm 1.06$ & $10.18 \pm 0.87$ & $141-1438$ & $458 \pm 236$ & 3.14 \\
\hline Chaetodon capistratus & Foureye butterflyfish & 14 & $-13.27 \pm 0.76$ & $9.53 \pm 0.59$ & $138-527$ & $312 \pm 118$ & 3.20 \\
\hline Gerres cinereus & Yellow fin mojarra & 4 & $-11.85 \pm 0.84$ & $8.16 \pm 0.88$ & $64-1162$ & $407 \pm 519$ & 2.79 \\
\hline Haemulon flavolineatum & French grunt & 3 & $-13.57 \pm 0.47$ & $10.24 \pm 0.64$ & $977-1480$ & $1279 \pm 267$ & 3.41 \\
\hline Haemulon plumieri & White grunt & 18 & $-14.15 \pm 1.54$ & $9.97 \pm 0.77$ & $343-2557$ & $987 \pm 565$ & 3.33 \\
\hline Jenkinsia lamprotaenia & Dwarf round herring & 50 & $-16.85 \pm 1.58$ & $8.38 \pm 0.57$ & $45-830$ & $139 \pm 121$ & 2.86 \\
\hline Lutjanus analis & Mutton snapper & 3 & $-11.84 \pm 0.98$ & $8.72 \pm 0.17$ & $180-411$ & $304 \pm 117$ & 2.96 \\
\hline Lutjanus campechanus & Northern red snapper & 8 & $-14.94 \pm 2.22$ & $9.94 \pm 0.56$ & $164-865$ & $375 \pm 226$ & 3.32 \\
\hline Lutjanus synagris & Lane snapper & 14 & $-14.77 \pm 1.02$ & $9.49 \pm 0.51$ & $118-364$ & $214 \pm 83$ & 2.99 \\
\hline Scarus iseri & Striped parrotfish & 3 & $-12.70 \pm 0.14$ & $7.35 \pm 1.59$ & $61-89$ & $77 \pm 14$ & 2.56 \\
\hline Tursiops truncatus & Bottlenose dolphin & 37 & $-13.05 \pm 1.89$ & $10.25 \pm 1.48$ & $113-4627$ & $1637 \pm 1387$ & 3.41 \\
\hline
\end{tabular}


Table 2. Summarized values used in the risk assessment of bottlenose dolphins (Tursiops truncatus) in Bocas del Toro, Panama based on Hung et al. calculations (2004; 2006).

\begin{tabular}{|c|c|}
\hline Variable & Bottlenose dolphin values \\
\hline $\mathrm{Hg}$ concentration in all prey $(\mathrm{CF})$ & $5587 \mathrm{ng} \mathrm{g}^{-1} \mathrm{ww}$ \\
\hline Ingestion rate $(I R)$ & $5.48 \mathrm{~kg}$ day $^{-1}$ (Kastelein et al., 2002) \\
\hline Exposure frequency $(E F)$ & 365 days year ${ }^{-1}$ \\
\hline Exposure duration $(E D)$ & $\begin{array}{l}45 \text { years - assuming life-time exposure } \\
\text { (Jefferson et al., 2002) }\end{array}$ \\
\hline Body weight $(B W)$ & 260 kg (Kastelein et al., 2002) \\
\hline Average time $(A T)$ & 16425 (45 × 365 days $)$ \\
\hline Reference dose (RfD) & $118 \mathrm{mg} \mathrm{kg}^{-1} \mathrm{ww}_{\text {day }}{ }^{-1}$ \\
\hline $\begin{array}{l}\text { Maximum Allowable } \\
\text { Concentration }\left(M A C_{R f d}\right)\end{array}$ & $5587 \mathrm{ng} \mathrm{g}^{-1} \mathrm{ww}$ \\
\hline
\end{tabular}


Table 3. Total mercury ( $\mathrm{THg}$ ) skin concentrations (ng g ${ }^{-1} \mathrm{dw}$ ) of free ranging bottlenose dolphins (Tursiops truncatus), Commerson's dolphin (Cephalorhynchus commersonii), common dolphin (Delphinus delphis), harbour porpoise (Phocoena phocoena), and striped dolphin (Stenella coeruleoalba) reported in the literature. Data are shown as sample location, sample year, sample number (n), THg mean \pm standard deviation, and the study reference.

\begin{tabular}{|c|c|c|c|c|c|}
\hline Location & Year & $\mathrm{n}$ & $\begin{array}{l}\mathrm{THg} \\
\text { Min-max }\end{array}$ & $\begin{array}{l}\text { THg } \\
\text { Mean } \pm \text { SD }\end{array}$ & Reference \\
\hline \multicolumn{6}{|c|}{ Bottlenose dolphin (Tursiops truncatus) } \\
\hline Bocas del Toro (Panama) & 2012-2016 & 37 & $113-4627$ & $1637 \pm 1387$ & This study \\
\hline La Guajira (Colombia) & 2016 & 7 & $2720-10590$ & $5526 \pm 3209$ & This study \\
\hline Lower Florida Keys (FL, USA) & 2008 & 9 & $294-5713$ & $2936 \pm 2083$ & Damseaux et al., 2017 \\
\hline Everglades (FL, USA) & 2013 & 9 & Female: $4509-29 \mathrm{M} 125$ & $12313 \pm 8735$ & Damseaux et al., 2017 \\
\hline Everglades (FL, USA) & 2013 & 13 & Male: $2221-28761$ & $10048 \pm 6637$ & Damseaux et al., 2017 \\
\hline Sarasota Bay (FL, USA) & $2003-2005$ & 54 & $322-7685$ & $2152 \pm 1680$ & Woshner et al., 2008 \\
\hline Charleston (SC, USA) & 2003-2005 & 74 & $650-4900$ & $1700 \pm 920$ & Stavros et al., 2007 \\
\hline Indian River Lagoon (FL, USA) & $2003-2005$ & 75 & $330-31000$ & $7000 \pm 5900$ & Stavros et al., 2007 \\
\hline Bay of Biscay, Atlantic Ocean & $2001-2008$ & 16 & $2200-14400$ & $5700 \pm 2900$ & Aubail et al., 2013 \\
\hline \multicolumn{6}{|c|}{ Commerson's dolphin (Cephalorhynchus commersonii) } \\
\hline Tierra del Fuego (Argentina) & 2010-2012 & 9 & $680-3110$ & $1380 \pm 850$ & Cáceres-Saez et al., 2015 \\
\hline \multicolumn{6}{|c|}{ Common dolphin (Delphinus delphis) } \\
\hline Bay of Biscay, Atlantic Ocean & $2001-2008$ & 79 & $200-3500$ & $1700 \pm 700$ & Aubail et al., 2013 \\
\hline \multicolumn{6}{|c|}{ Harbour porpoise (Phocoena phocoena) } \\
\hline Bay of Biscay, Atlantic Ocean & $2001-2008$ & 17 & $800-3300$ & $1600 \pm 700$ & Aubail et al., 2013 \\
\hline \multicolumn{6}{|c|}{ Striped dolphin (Stenella coeruleoalba) } \\
\hline Bay of Biscay, Atlantic Ocean & $2001-2008$ & 19 & $1030-6800$ & $3000 \pm 1700$ & Aubail et al., 2013 \\
\hline
\end{tabular}

